\title{
Distinct Brain Vascular Cell Types Manifest Inducible Cyclooxygenase Expression as a Function of the Strength and Nature of Immune Insults
}

\author{
Jennifer C. Schiltz and Paul E. Sawchenko \\ Laboratory of Neuronal Structure and Function, The Salk Institute for Biological Studies and Foundation for Medical \\ Research, La Jolla, California 92037
}

Induced prostanoid synthesis by cells associated with the cerebral vasculature has been implicated in mediating immune system influences on the CNS, but the cell type(s) involved remain unsettled. To determine whether this might derive from differences in the nature and intensity of the stimuli used to model immune insults, immunochemical and hybridization histochemical methods were used to monitor cyclooxygenase-2 (COX-2) expression alone, or in conjunction with endothelial, perivascular, and glial cell markers, in brains of rats treated with varying doses of interleukin-1 (IL-1) or bacterial lipopolysaccharide (LPS). Vehicle-treated animals displayed weak COX-2 expression in the meninges, choroid plexus, and larger blood vessels. Rats challenged intravenously with IL-1 $\beta$ (1.87-30 $\mu \mathrm{g} /$ $\mathrm{kg}$ ) showed a marked increase in the number of vascularassociated cells displaying COX-2-immunoreactivity (ir). More than $90 \%$ stained positively for the ED2 macrophage differen- tiation antigen, identifying them as perivascular cells, whereas none coexpressed endothelial or glial cell markers. Low doses of LPS $(0.1 \mu \mathrm{g} / \mathrm{kg})$ elicited a similar response profile, but higher doses (2-100 $\mu \mathrm{g} / \mathrm{kg})$ provoked COX-2 expression in a progressively greater number of cells exhibiting distinct round or multipolar morphologies, corresponding to cells expressing endothelial (RECA-1) or perivascular (ED2) cell antigens, respectively. Similarly, ultrastructural analysis localized COX2-ir to the perinuclear region of endothelial cells of LPS-treated but not IL-1-treated rats. We conclude that perivascular cells exhibit the lower threshold to COX-2 expression in response to either IL-1 or endotoxin treatment, and that enzyme expression by endothelial cells requires one or more facets of the more complex immune stimulus presented by LPS.

Key words: endothelial cells; HPA axis; interleukin-1; lipopolysaccharide; perivascular cells; prostaglandins
During infectious and inflammatory episodes, cytokines act on the brain to elicit such adaptive responses as fever, anorexia, somnolence, lethargy, and metabolic effects, including activation of the hypothalamo-pituitary-adrenal (HPA) axis (Dinarello, 1984, 1988; Elmquist et al., 1997b; Dantzer et al., 1998; Krueger et al., 1999). One such factor, interleukin-1 (IL-1), is released from activated macrophages and can itself elicit each of these central acute phase responses (Dinarello, 1984, 1991; Besedovsky et al., 1986; Sapolsky et al., 1987). Because IL-1 is not believed to cross the blood-brain barrier in biologically significant concentrations, the mechanisms that might provide access have been studied extensively, and several alternative routes have been proposed (Watkins et al., 1995; Blatteis and Sehic, 1997; Elmquist et al., 1997b). Entry at circumventricular organs, transduction by peripheral nerves, facilitated transport across the barrier, and cytokine-receptor interactions at the brain-fluid interfaces with consequent release of local signaling molecules, each of which might allow direct or afferent-mediated access to relevant effector

\footnotetext{
Received Jan. 18, 2002; revised March 25, 2002; accepted April 12, 2002.

This research was supported by National Institutes of Health Grant NS-21182 and was conducted in part by the Foundation for Medical Research. P.E.S. is an investigator of the Foundation for Medical Research. J.C.S. was the recipient of National Research Service Award support 5 F32 NS10695. We thank Carlos Arias, Casey Peto, and Kris Trulock for excellent technical and photographic expertise, respectively.

Correspondence should be addressed to Dr. Paul E. Sawchenko, Laboratory of Neuronal Structure and Function, The Salk Institute, 10010 North Torrey Pines Road, La Jolla, CA 92037. E-mail: sawchenko@salk.edu.

Copyright (C) 2002 Society for Neuroscience $0270-6474 / 02 / 225606-13 \$ 15.00 / 0$
}

populations, have all been considered as a basis for such interactions (Dantzer, 1994; Watkins et al., 1995; Ericsson et al., 1996).

Findings from several laboratories support the view that circulating cytokines can be monitored by non-neuronal cells associated with the cerebral vasculature, which appear capable of engaging proximate afferent projections to relevant effector neurons, including those involved in HPA control, through the local release of prostaglandins (Ericsson et al., 1997; Scammell et al., 1998). Prostaglandin levels within the brain are elevated after bacterial lipopolysaccharide (LPS) administration (Sehic et al., 1996), and blocking induced synthesis with aspirin-like drugs can disrupt cytokine-mediated activation of the HPA axis (Katsuura et al., 1988). Brain vascular cells express IL-1 receptors (Ericsson et al., 1995) and display inducible expression of cyclooxygenase-2 (COX-2), the rate-limiting enzyme in prostanoid biosynthesis, as well as prostaglandin E2 (PGE2), in response to certain immune challenges (Elmquist et al., 1997a; Lacroix and Rivest, 1998; Matsumura et al., 1998; Quan et al., 1998).

Further understanding of prostanoid mechanisms in immuneto-brain signaling has been limited by uncertainly as to the identity of the vascular cell type(s) capable of induced COX-2 expression and the conditions under which this capacity may be invoked (Rivest, 1999). For example, cells identified as perivascular microglia were reported to be the dominant source of vascular COX-2 induction in rats treated intravenously with moderate doses of LPS (Elmquist et al., 1997a), whereas another group has identified endothelial cells as the only vascular cell type to express COX-2 after intraperitoneal IL-1 or LPS (Cao et al., 1996; Matsumura et al., 1998). Still others describe LPS-induced 
COX-2 expression mainly in endothelial cells, but with a few perivascular cells also exhibiting this capacity (Quan et al., 1998). Most previous studies on this topic have used relatively high doses of LPS, and responses to individual cytokines at doses nearer the threshold for eliciting acute phase responses have not been systematically explored.

In line with an effort to clarify the mechanisms underlying IL-1-mediated activation of HPA control circuitry, we studied COX-2 expression induced in response to intravenous IL-1 at a dose moderately above the threshold required for HPA activation and characterized the morphology and phenotype of responsive cells. Similar analyses were conducted in rats given graded doses of LPS in an attempt to reconcile the conflicting literature on this topic. LPS, a cell wall component of Gram-negative bacteria, was used as a model of immune activation because it induces the release of multiple proinflammatory cytokines, including IL-1, and has recently been shown to account for very nearly the entire bacterial response of certain immune (dendritic) cells (Huang et al., 2001).

Portions of these data have been presented previously in abstract form (Schiltz and Sawchenko, 2000).

\section{MATERIALS AND METHODS}

Animals. Adult male Sprague Dawley albino rats (260-340 gm) were used in all experiments. They were housed individually in a temperaturecontrolled room on a $12 \mathrm{hr}$ light/dark cycle with food and water ad libitum and were adapted to handling for at least $5 \mathrm{~d}$ before any manipulation. All experimental protocols were approved by the Institutional Animal Care and Use Committee of the Salk Institute.

Intravenous administration of $I L-1 \beta$ and LPS. The procedures for implanting catheters and intravenous infusions have been described previously (Ericsson and Sawchenko, 1993; Ericsson et al., 1994). Briefly, indwelling jugular catheters (PE 50) containing sterile, heparin-saline $(50 \mathrm{U} / \mathrm{ml})$ were implanted under methoxyflurane anesthesia. The sealed catheter was positioned with its internal SILASTIC (Dow Corning) tip at the atrium and was exteriorized at an interscapular position. After $2 \mathrm{~d}$ recovery, awake and freely moving rats were removed briefly from their home cage, injected with $1.87,10$, or $30 \mu \mathrm{g} / \mathrm{kg}$ of recombinant human IL-1 $\beta$ (generously provided by Dr. S. Gillis, Immunex, Seattle, WA) or its vehicle $(1 \mathrm{ml} / \mathrm{kg}, 0.01 \%$ BSA, $0.01 \%$ ascorbic acid, $10 \mathrm{~mm}$ Tris- $\mathrm{HCl}$, $36 \mathrm{~mm}$ sodium phosphate buffer, $\mathrm{pH}$ 7.4) and returned to their home cages. In similar experiments, groups of rats were injected with lipopolysaccharide at varying doses $(0.1,2.0$, or $100 \mu \mathrm{g} / \mathrm{kg}$; Sigma, serotype 055:B5) or sterile saline $(1 \mathrm{ml} / \mathrm{kg})$.

Intraventricular indomethacin injections. Groups of rats $(n=5$ per group) were anesthetized with ketamine/xylazine/acepromazine (25:5:1 $\mathrm{mg} / \mathrm{kg}$, s.c.) and stereotaxically implanted with guide cannulas (Plastics One) terminating within a lateral ventricle. The cannulas were affixed to the skull with dental acrylic adhering to jewelers screws partially driven into the skull and were sealed with dummy stylets cut to terminate flush with the tip of the cannula. Seven to $10 \mathrm{~d}$ later, and $2 \mathrm{~d}$ after implantation of jugular catheters, the stylets were removed and replaced with 30 ga injection cannulas that extended $1.0 \mathrm{~mm}$ beyond the tip of the guide. Rats were given intracerebroventricular injections of indomethacin $(10 \mu \mathrm{g}$ in $5 \mu \mathrm{l})$ or vehicle $(5 \mu \mathrm{l}, 0.04 \mathrm{M}$ PBS with $10 \%$ ethanol and $0.1 \%$ ascorbic acid, pH 6.0) through the injection cannula connected to a $50 \mu \mathrm{l} \mathrm{Ham-}$ ilton syringe with PE 50 tubing. Fifteen minutes after the brain injection, IL-1 $(1.87 \mu \mathrm{g} / \mathrm{kg})$ or vehicle was administered intravenously. Two hours later, the animals were anesthetized and perfused for histology.

Histology and tissue processing. At appropriate time points (between 0.5 and $6 \mathrm{hr}$ after injection), rats were anesthetized with chloral hydrate (350 $\mathrm{mg} / \mathrm{kg}$, i.p.) and perfused via the ascending aorta with saline followed by $700 \mathrm{ml}$ of $4 \%$ paraformaldehyde in $0.1 \mathrm{M}$ borate buffer, $\mathrm{pH} 9.5$, at $10^{\circ} \mathrm{C}$. The brains were removed, postfixed for $3 \mathrm{hr}$, and cryoprotected in $10-15 \%$ sucrose in $0.1 \mathrm{M}$ phosphate buffer overnight at $4^{\circ} \mathrm{C}$. Five onein-five series of frozen coronal sections $(30 \mu \mathrm{m})$, either through the whole brain or through medulla and hypothalamus, were collected in cryoprotectant solution and stored at $-20^{\circ} \mathrm{C}$ until processing.

Immunohistochemistry. COX-2 and Fos proteins were detected by localization of antisera raised against a peptide corresponding to amino acids 584-604 mapping at the $\mathrm{C}$ terminus of the rat $\mathrm{COX}-2$ precursor (raised in goat; Santa Cruz Biotechnology) and a rabbit polyclonal antiserum raised against an N-terminal fragment of human Fos protein (raised in rabbit; Santa Cruz Biotechnology), respectively. Analysis for Fos immunoreactivity (-ir) and COX-2-ir was performed on free-floating sections using a conventional avidin-biotin immunoperoxidase technique (Sawchenko et al., 1990). Sections were incubated with the primary antiserum at a dilution of 1:1000-1:5000 for COX-2 and 1:5000 for Fos at $4^{\circ} \mathrm{C}$ for $48 \mathrm{hr}$. The primary antiserum was localized using Vectastain Elite reagents, and the reaction product was developed on ice using a nickel-enhanced glucose oxidase method (Shu et al., 1988). The specificity of the antisera was confirmed in control experiments in which preabsorption overnight with $30-50 \mu \mathrm{M}$ of the synthetic peptide immunogens eliminated basal and induced staining.

The number of Fos-ir nuclear profiles was counted under $400 \times$ magnification in complete series of coronal sections through the ventrolateral medullary reticular formation from the level of the caudal pole of the facial motor nucleus to the spinal-medullary transition area and through the caudal half of the paraventricular nucleus of the hypothalamus (PVH) as defined by Swanson and Kuypers (1980), from the rostral pole of the posterior magnocellular subdivision through the caudalmost extent of the lateral parvocellular regions, thereby encompassing each of the key resident visceromotor populations (magnocellular neurosecretory, pre-autonomic, and parvocellular neurosecretory) housed within this cell group. Counting was performed without knowledge of treatment status, and estimates were corrected for double-counting errors using the method of Abercrombie (1946).

To identify the cell type(s) displaying COX-2-like immunoreactivity, a dual immunofluorescence protocol was used. Sections were incubated with antisera for COX-2 and either the macrophage differentiation antigen ED2, which serves as a marker for rat perivascular and meningeal macrophages (1:1500; Serotec) (Dijkstra et al., 1985; Graeber et al., 1989), or a marker for endothelial cells (RECA-1 antigen, 1:1000; Serotec) (Duijvestijn et al., 1992), microglia (OX42, 1:1000; Serotec) or astroglia (glial fibrillary acidic protein, $1: 1000$; Incstar) for $48 \mathrm{hr}$ at $4^{\circ} \mathrm{C}$. Subsequently, the sections were incubated for 1-2 hr at room temperature with affinity-purified Cy3-conjugated donkey anti-mouse $\operatorname{IgG}(1: 200$; Jackson ImmunoResearch) and fluorescein-conjugated donkey anti-goat IgG (1:200; Jackson ImmunoResearch) to localize ED2, RECA-1, and OX-42 or COX-2, respectively. The astroglia marker was visualized with an affinity-purified Cy3-conjugated donkey anti-rabbit IgG (1:200; Jackson ImmunoResearch). Control experiments included incubation of tissue sections from control and challenged animals with each antiserum singly and then with both secondary antisera to ensure that the latter did not cross-react with the inappropriate primary antiserum or with each other. Imaging was performed using a Bio-Rad MRC1000UV scanning confocal laser microscope (SCLM; courtesy of Dr. F. Gage, The Salk Institute, La Jolla, CA) equipped with a krypton/argon laser and Lasersharp software.

To determine whether IL-1 treatment might alter the number of detectable ED2-ir cells, estimates of their density were obtained in subgroups $(n=3)$ of rats killed $2 \mathrm{hr}$ after vehicle or IL-1 injection (1.87 $\mu \mathrm{g} / \mathrm{kg}$ ). Two regions were selected for analysis on the basis of their tendency to contain substantial numbers of ED2-positive cells; the C1 region of the ventrolateral medulla and the aspect of endopiriform nucleus just ventral to the external capsule at the level of the medial preoptic nucleus. In each case, the number of ED-2-positive cells in a $1.13 \mathrm{~mm}^{2}$ grid was determined in sections taken at $150 \mu \mathrm{m}$ intervals through the regions of interest, and the average density of immunolabeled cells was determined for each region in each animal.

In situ hybridization histochemistry. COX-2 mRNA was detected using a ${ }^{35}$ S-labeled antisense cRNA probe transcribed from a $0.2 \mathrm{~kb}$ cDNA (Dr. Serge Rivest, Laval University). Control sense probes were generated from the same cDNA clone and labeled to similar specific activities. Transcripts encoding the type $1 \mathrm{IL}-1$ receptor (IL-1R1) was detected using a ${ }^{35}$ S-labeled antisense cRNA probe transcribed from a $1.4 \mathrm{~kb}$ cDNA (Dr. Ron Hart, Rutgers University). Hybridization histochemical localization was performed as described previously (Simmons et al., 1989). Briefly, sections were mounted onto gelatin and poly-L-lysinecoated slides and desiccated under vacuum overnight. They were then postfixed with neutral buffered formalin for $30 \mathrm{~min}$, digested in $10 \mu \mathrm{g} / \mathrm{ml}$ proteinase $\mathrm{K}$ at $37^{\circ} \mathrm{C}$ for $30 \mathrm{~min}$, acetylated for $10 \mathrm{~min}$, and then dehydrated and vacuum dried for several hours. After prehybridization treatments, sections were hybridized at $55^{\circ} \mathrm{C}$ for $48 \mathrm{hr}$ with antisense riboprobes synthesized using $\left[{ }^{35} \mathrm{~S}\right]-\mathrm{UTP}$ and -ATP $\left(10^{6} \mathrm{pm} / 100 \mu \mathrm{l}\right.$ per 

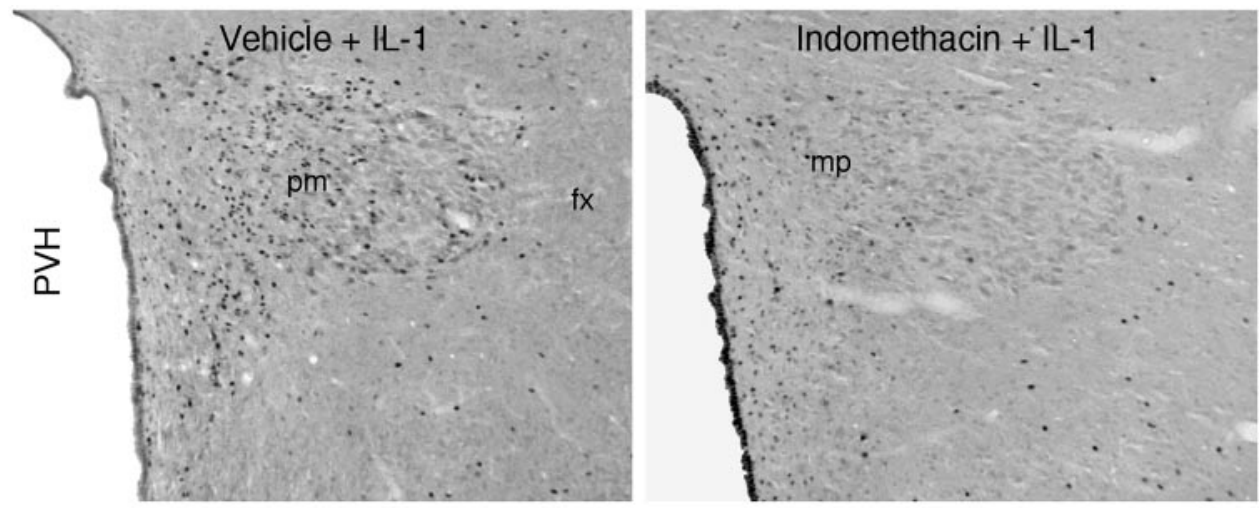

Figure 1. Central prostaglandin synthesis blockade disrupts systemic IL-1-induced activation of the paraventricular nucleus and its aminergic afferents. Bright-field photomicrographs show IL-1-induced Fos-ir expression in the paraventricular nucleus $(P V H, t o p)$ and the $\mathrm{C} 1$ region of the ventrolateral medulla (VLM, bottom) in rats pretreated by intracerebroventricular injection of vehicle (left) or indomethacin $(10 \mu \mathrm{g} / 5 \mu \mathrm{l})($ right $)$. As reported previously, intravenous IL-1 $(1.87 \mu \mathrm{g} / \mathrm{kg})$ evokes a robust Fos response within the PVH and $\mathrm{C} 1$ regions. However, pretreatment with central infusion of indomethacin, a nonselective inhibitor of COX activity, results in a marked diminution of IL- 1 effects at the levels of both medulla and hypothalamus. This finding supports the view that induced synthesis of prostaglandins within the brain is required for the activation of HPA control systems in response to systemic (intravenous) IL-1. Scale bar, $100 \mu \mathrm{m}$.
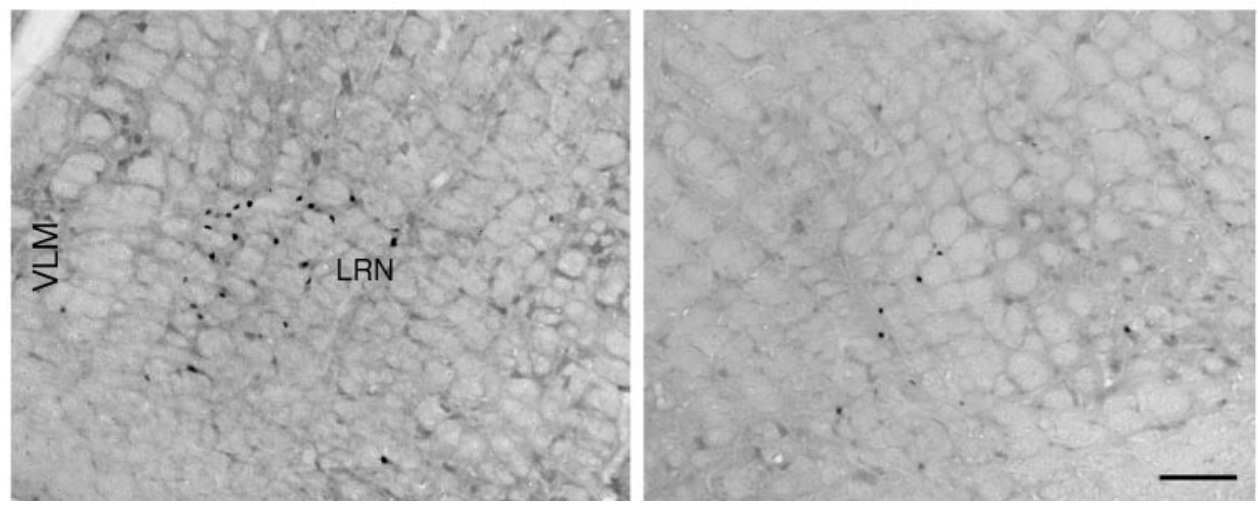

slide) and diluted in hybridization buffer consisting of $247 \mathrm{~mm} \mathrm{NaCl}, 8.2$ Tris- $\mathrm{HCl}, \mathrm{pH} 8.0$, at $25^{\circ} \mathrm{C}, 41 \%$ (v/v) formamide, $0.82 \times$ Denhardt's solution ( $50 \times$ bovine serum albumin, ficoll, and polyvinylpyrrolidone), $8.2 \%(\mathrm{w} / \mathrm{v})$ dextran sulfate, $411 \mu \mathrm{g} / \mathrm{ml}$ yeast tRNA, and $8.2 \mathrm{~mm}$ DTT. Post-hybridization treatments included four initial rinses in $4 \times$ SSC and incubation in RNase A $\left(20 \mu \mathrm{g} / \mathrm{ml}, 37^{\circ} \mathrm{C}, 30 \mathrm{~min}\right)$, followed by a high stringency wash in $0.1 \times \mathrm{SSC}$ at $65-70^{\circ} \mathrm{C}$. The slides were rinsed in $0.1 \times$ SSC $(0.15 \mathrm{M} \mathrm{NaCl}$ and $0.015 \mathrm{M}$ citric acid), dehydrated, and dried. Slides were exposed to Amersham $\beta$-max autoradiography film overnight, defatted in graded ethanols and xylenes, and dipped in Kodak NTB-2 nuclear track emulsion. Slides were exposed for 15-28 d and developed in D-19 developer (Kodak) for $5 \mathrm{~min}$ at $14^{\circ} \mathrm{C}$. In some cases, sections were then counterstained with thionin, dehydrated, and coverslipped.

Combined immunochemistry and hybridization histochemistry for ED2-ir and IL-1R1 mRNA was performed using minor modifications (Chan et al., 1993) of a procedure described by Watts and Swanson (1989). Immunostaining was performed first, and the individual methods were modified as follows: (1) nonimmune (blocking) sera, potential sources of RNase contamination, were replaced with $2 \%$ heparin sulfate and $2 \% \mathrm{BSA},(2)$ nickel enhancement steps were eliminated from the immunostaining protocol because nickel-based reaction product does not survive the hybridization steps, (3) tissue pretreatment with hydrogen peroxide was omitted, and (4) Nissl counterstaining was omitted.

Electron microscopy. Rats received an intravenous injection of 1.87 $\mu \mathrm{g} / \mathrm{kg} \mathrm{IL}-1$ and were perfused $2 \mathrm{hr}$ later with saline followed by $2 \%$ paraformaldehyde and $2.75 \%$ acrolein in $0.1 \mathrm{M}$ phosphate buffer, $\mathrm{pH}$ 7.0. Vibratome sections $(50 \mu \mathrm{m}$ thick) were then prepared for avidin-biotin immunoperoxidase localization of COX-2 or ED2 as described above. Sections were fixed in $1 \%$ osmium tetroxide with $1.5 \%$ potassium ferricyanide, dehydrated with ethanol and propylene oxide, and infiltrated with Spurr's resin. The sections were embedded, thin sectioned, and counterstained with uranyl acetate and lead citrate. A similar protocol was followed for rats given LPS except that they were perfused $4 \mathrm{hr}$ after injection of $100 \mu \mathrm{g} / \mathrm{kg}$ LPS. The material was examined in a JEOL 100 CX II transmission electron microscope.

Statistics. Counts of Fos-positive cells within the paraventricular nucleus and ventrolateral medulla were analyzed by one-way ANOVA for each region followed by Fischer LSD post hoc tests.

Imaging. Most images either were captured digitally, using an Orca 100 digital CCD camera (Hamamatsu) and Openlab software (Improvision), or were recorded on Kodak Ektachrome 160 positive film or $70 \mathrm{~mm}$ EM plates and digitized using a Kodak RS-3570 film scanner. All were imported into Adobe Photoshop (v. 5.5), cropped, adjusted to balance brightness and contrast, exported to Canvas (v. 7.0) for assembly, and rendered at 300 dpi using a Kodak PS-8600 dye sublimation printer.

\section{RESULTS}

\section{Effect of central prostaglandin synthesis inhibition on IL-1-induced activational responses}

To determine whether induced synthesis of prostaglandins within the brain is required for the activation of HPA control circuitry observed in response to a systemic (intravenous) IL-1 challenge, rats were instrumented with chronic indwelling catheters placed within the lateral ventricle and given indomethacin, a nonselective inhibitor of COX activity, or its vehicle, 15 min before an intravenous infusion of vehicle or IL-1. Analyses focused on the PVH (the seat of neurosecretory neurons providing for HPA control) and the ventrolateral medulla (the principal source of IL-1-sensitive catcholaminegic inputs to the $\mathrm{PVH}$, on whose integrity the hypothalamic response depends) (Ericsson et al., 1994). Fos-ir expression in animals treated centrally and systemically with vehicle was low to undetectable in both the PVH and ventrolateral medulla. As reported previously (Ericsson et al., 1994), intravenous IL-1 evokes a robust Fos response within the $\mathrm{PVH}$ and the regions of catecholaminergic cell groups in the nucleus of the solitary tract and ventrolateral medulla. Pretreatment with a central infusion of indomethacin produced no significant effect on basal levels of Fos expression in either brainstem or hypothalamus, but did result in a reliable diminution of IL-1 effects at the levels of both the ventrolateral medulla (51\%) and PVH $(83 \%)$ (Figs. 1, 2). It should be noted that central indomethacin treatment did elicit Fos induction throughout the ependymal lining of the ventricular system, which we attribute to nonspecific bulk effects of intracerebroventricular injection of solute (Bittencourt and Sawchenko, 2000). 

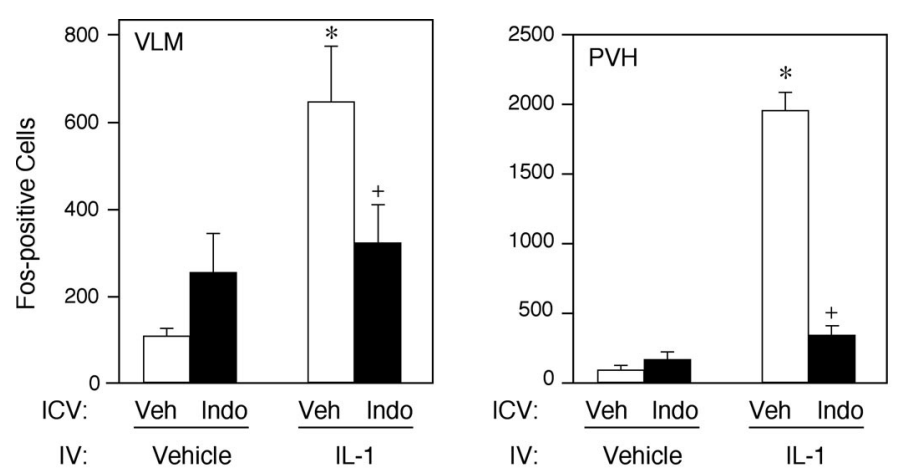

Figure 2. Effects of central indomethacin on IL-1-induced Fos expression in hypothalamus and ventrolateral medulla. Mean \pm SEM number of Fos-ir neurons in the ventrolateral medulla (VLM, left) and PVH (right) and in rats pretreated centrally $(I C V)$ with $10 \mu \mathrm{g}$ indomethacin (Indo) or vehicle $(V e h)$, and systemically $(I V)$ with $1.87 \mu \mathrm{g} / \mathrm{kg}$ IL-1. Indomethacin treatment results in a marked diminution of IL-1 effects at the levels of both medulla and hypothalamus. Neither of the groups pretreated with indomethacin had counts in either region that were significantly different from those in the Veh/Veh control group. ${ }^{*} p<0$. 01 compared with Veh/Veh group. ${ }^{+} p<0.05$ compared with Veh/IL-1 group ( $n=5$ per group).

\section{Basal and IL-1-induced COX-2 expression}

After confirming that prostaglandin synthesis within the brain was required for IL-1-induced Fos expression within key elements of HPA control circuitry, the sites of basal and cytokinestimulated expression of COX-2 were evaluated at the mRNA and protein levels. A total of 14 unmanipulated or vehicle-treated and 18 IL-1-injected rats were used in the analysis. In vehicletreated animals, the most prominent sites of COX-2 mRNA signal were over presumed neurons in a few discrete regions of the brain (Fig. 3). These included strong and continuous labeling over the principal cell layers of the dentate gyrus and Ammon's horn of the hippocampal formation, a somewhat lesser density and intensity of labeling over piriform cortex, and scattered, positively labeled cells in the superficial parts of layer $2 / 3$ distributed roughly evenly throughout the isocortex. In addition, isolated examples of above-background accumulations of silver grains were seen over the meninges and some larger blood vessels. It was not possible to discern in this material the extent to which the somewhat greater density of positively hybridized cells over the area postrema conformed to labeling of neurons versus vascular-associated cells. IL-1 treatment consistently resulted in no apparent alteration in neuronal COX-2 mRNA expression over a range of doses $(1.87-30 \mu \mathrm{g} / \mathrm{kg})$ and at varying time points after injection $(0.5-6 \mathrm{hr})$, although the number of cells associated with the vasculature and the meninges clearly showed induced expression of the transcript. This extended to smaller caliber vessels and capillaries. A time course analysis indicated that IL-1-induced COX-2 mRNA expression is detectable by $30 \mathrm{~min}$ after injection, peaks 1-2 hr after treatment, and diminishes to control levels by $4 \mathrm{hr}$ (data not shown).

Complementary analyses of immunoreactive COX-2 expression were undertaken in groups of rats killed at 2, 4, and $6 \mathrm{hr}$ after vehicle or IL-1 injection. In agreement with findings at the mRNA level, constitutive COX-2-ir was present within cortical neurons whose distribution mirrored that described above (Fig. 4). Similarly, lesser numbers of weakly stained cells were seen in the meninges and perivascular regions (Fig. 4). Those associated with vasculature displayed an irregular, polygonal, or multipolar morphology, whereas positively labeled cells in the meninges ranged between round and polygonal in shape. Although no alteration in neuronal staining was apparent at any interval after IL-1 treatment, a clear increase in the number and staining intensity of COX-2-positive cells was observed at 2 or $4 \mathrm{hr}$ after treatment within the meninges, choroid plexus, and perivascular regions throughout the brain. COX-2-ir cells were not observed within all blood vessels and were seen most commonly in association with larger diameter ones, particularly penetrating arterioles. Furthermore, some regional specificity of COX-2-ir distribution was evident in that vessel-associated COX-2-ir cells were most numerous in ventral regions of both the forebrain and brainstem, with somewhat more prominent accumulations seen at the levels of rostral medulla and the preoptic region, where vessels near the ventral-most extension of the external capsule showed particularly dense accumulations of positively stained cells. Of the time points examined, induced $\mathrm{COX}$-2-ir in non-neuronal elements was detectable at $2 \mathrm{hr}$, maximal in most regions at $4 \mathrm{hr}$, and reduced but not eliminated by $6 \mathrm{hr}$ after injection (data not shown).

\section{Identification of IL-1-sensitive non-neuronal elements}

Results of dual immunolabeling of material from IL-1-challenged rats revealed that very nearly all COX-2-ir cells also stained positively for the ED2 antigen, suggesting that they may be considered "perivascular cells" as defined by Graeber et al. (1989) (Fig. 5). More than $90 \%$ of all COX-2-stained cells both in the meninges and associated with the cerebral microvasculature colabeled for ED2-ir in a sampling from various brain levels and IL-1 dosage conditions. The isolated examples that failed to exhibit COX-2-ir were never found to colocalize with the endothelial marker, RECA-1 (Fig. 5), suggesting that endothelial cells do not manifest substantial COX-2 expression in this paradigm. Dual staining for COX-2-ir and either OX42 or GFAP-ir also failed to identify doubly labeled cells, suggesting that neither parenchymal microglia nor astroglia manifest COX-2 induction in response to an IL-1 challenge (data not shown).

To further investigate the morphology and disposition of vascular-associated cells that manifest inducible COX-2-ir, a fine structural analysis of ED2-ir and COX-2-ir was undertaken. Preembedding immunolabeling of 14 blocks derived from six rats through the medulla and ventral forebrain for ED2-ir labeled polygonal or multipolar cells in the perivascular space deep to the vascular basal lamina, but within the glial limitans (Fig. 6). They were distinguished by a relatively high density of lysosomes, multivesicular bodies, and vacuoles of varying sizes. Reaction product in ED2-stained material was restricted to the region at and just deep to the cell surface and rimmed smaller vacuoles, giving the appearance of endocytotic figures. In material from the same preparations, COX-2 immunostaining labeled cells of a similar form and that occupied a similar position with respect to other vascular-associated cell types. COX-2-ir differed in that it was distributed diffusely throughout the cytoplasm of labeled elements, giving no appearance of being associated with any particular organelle. Labeling was never observed in cells that comprised integral components of the vascular wall in material from animals treated with IL-1. In addition, and despite the appearance of some of the light-level staining patterns, positively labeled cells that lay clearly within the lumen of a vessel were never seen. This argues against the possibility that labeling of macrophages in the circulation may have contributed in any substantial way to the observed distribution. 

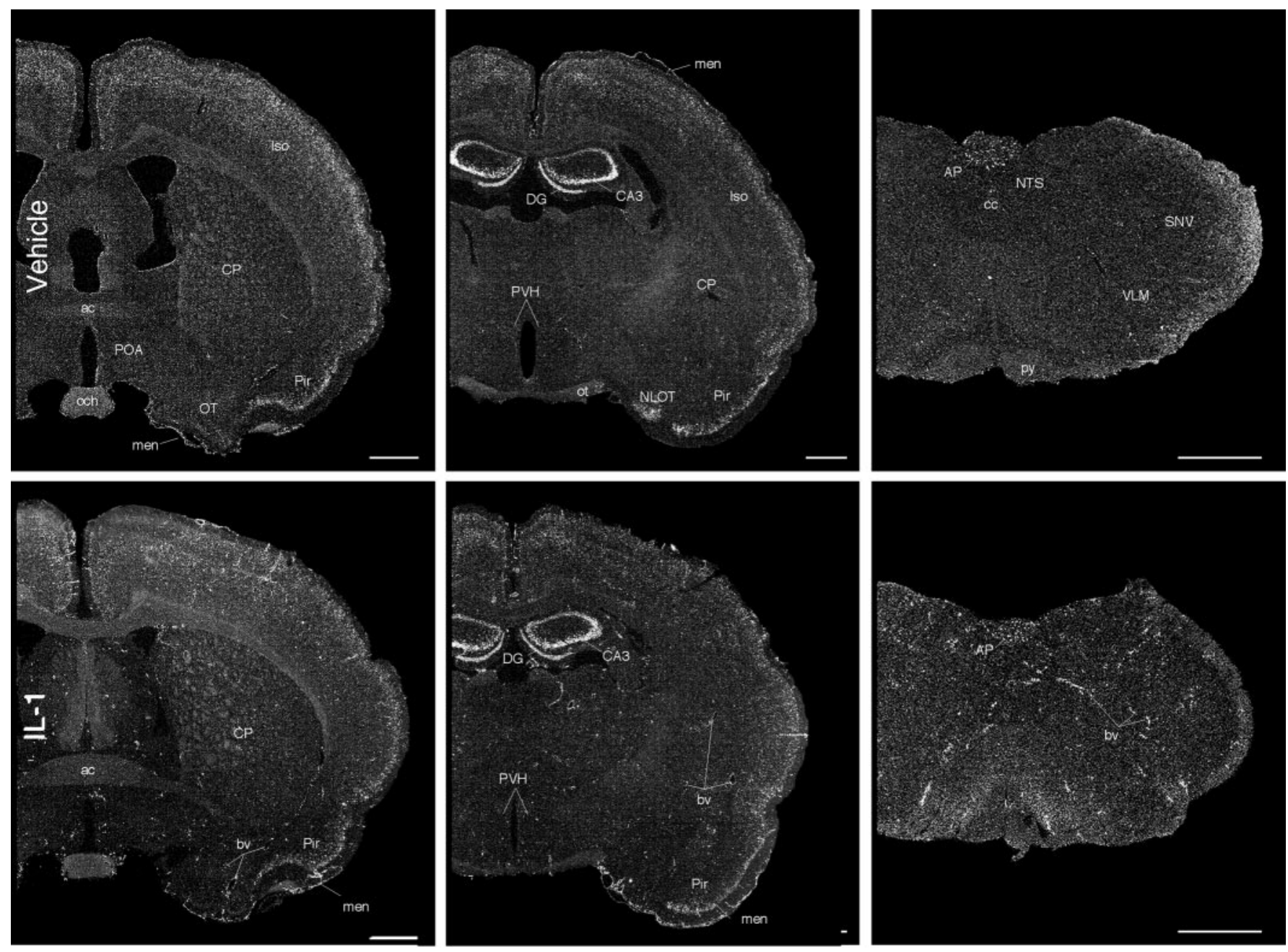

Figure 3. Basal and IL-1-stimulated COX-2 mRNA expression. Dark-field photomicrographs of sections from rats killed 1 hr after intravenous injection of vehicle (top row) or $1.87 \mu \mathrm{g} / \mathrm{kg} \mathrm{IL-1}$ (bottom row), at the levels of the preoptic area (left), paraventricular nucleus (middle), and medulla (right). In vehicle-treated rats, COX-2 mRNA is evident throughout the isocortex, hippocampal formation, and the area postrema. Some signal is also clearly evident within the meninges (men) and a few blood vessels $(b v)$. IL-1 treatment does not appear to alter neuronal expression of COX-2 mRNA, although expression by cells associated with the vasculature and the meninges is clearly increased throughout the brain. Scale bar, $100 \mu \mathrm{m}$. $a c$, Anterior commissure; och, optic chiasm; men, meninges; $O T$, olfactory tubercule; $C P$, caudate putamen; Pir, piriform cortex; iso, isocortex; $D G$, dentate gyrus; $C A 3$, field CA3 of ammon's horn; $N L O T$, nucleus of lateral olfactory tract; $A P$, area postrema; $c c$, central canal; $S N V$, spinal nucleus of trigeminal.

To determine whether perivascular cells express IL-1 receptors, and thus at least hold potential for being accessed directly by the cytokine, immunolocalization of ED2-ir was combined with hybridization histochemical detection of mRNA encoding the IL-1R1. Although the limited cellular resolution of the IL-1R1 mRNA signal precluded meaningful quantitative analysis, examples of positive hybridization signals associated with ED2-ir perivascular elements were observed regularly (Fig. 7). Cells labeled singly for each marker were also apparent in all sections, with ED2-labeling occurring in a clear minority of vascularassociated cells that displayed positive hybridization signals for IL-1R1 transcripts.

To assess the possibility that IL-1 treatment might affect the number of ED2-positive cells observed, the density of ED2stained cells in series of sections through representative regions of the forebrain and brain stem (see Materials and Methods) of vehicle- or IL-1-treated rats was assessed. In neither region did the density of immunolabeled cells observed in rats killed $2 \mathrm{hr}$ after intravenous IL-1 injection (forebrain: $25.4 \pm 2.9$; brainstem: $13.0 \pm 2.1$ cells $\left./ \mathrm{mm}^{2}\right)$ differ significantly $(p>0.10)$ from values obtained in vehicle-injected controls (forebrain: $21.4 \pm 2.8$; brainstem: $10.5 \pm 0.7$ cells $/ \mathrm{mm}^{2}$ ).

\section{Vascular cell types responsive to IL-1 versus LPS}

Because most recent reports (Matsumura et al., 1998; Quan et al., 1998) suggesting that endothelial cells are the primary seat of COX-2 induction have used moderate to high doses of LPS as an immune stimulus, we compared COX-2 induction in response to our standard dose of IL-1 $(1.87 \mu \mathrm{g} / \mathrm{kg})$ with that seen after 100 $\mu \mathrm{g} / \mathrm{kg}$ LPS. As was seen in response to IL-1, by $2-4 \mathrm{hr}$ after intravenous injection of $100 \mu \mathrm{g}$ LPS, a clear and robust increase in COX-2-ir was apparent within the meninges, choroid plexus, and vasculature-associated cells, as compared with the very low level of COX-2-ir observed in saline-treated rats (data not shown). Relative to material from IL-1-challenged animals, LPS provoked labeling of a greater number of cells distributed more densely over a greater number of vascular profiles, including capillaries (Fig. 8). Significantly, LPS-induced labeling associated with the vasculature differed in a qualitative manner from that seen in response to IL-1 in that labeled cells exhibited two 

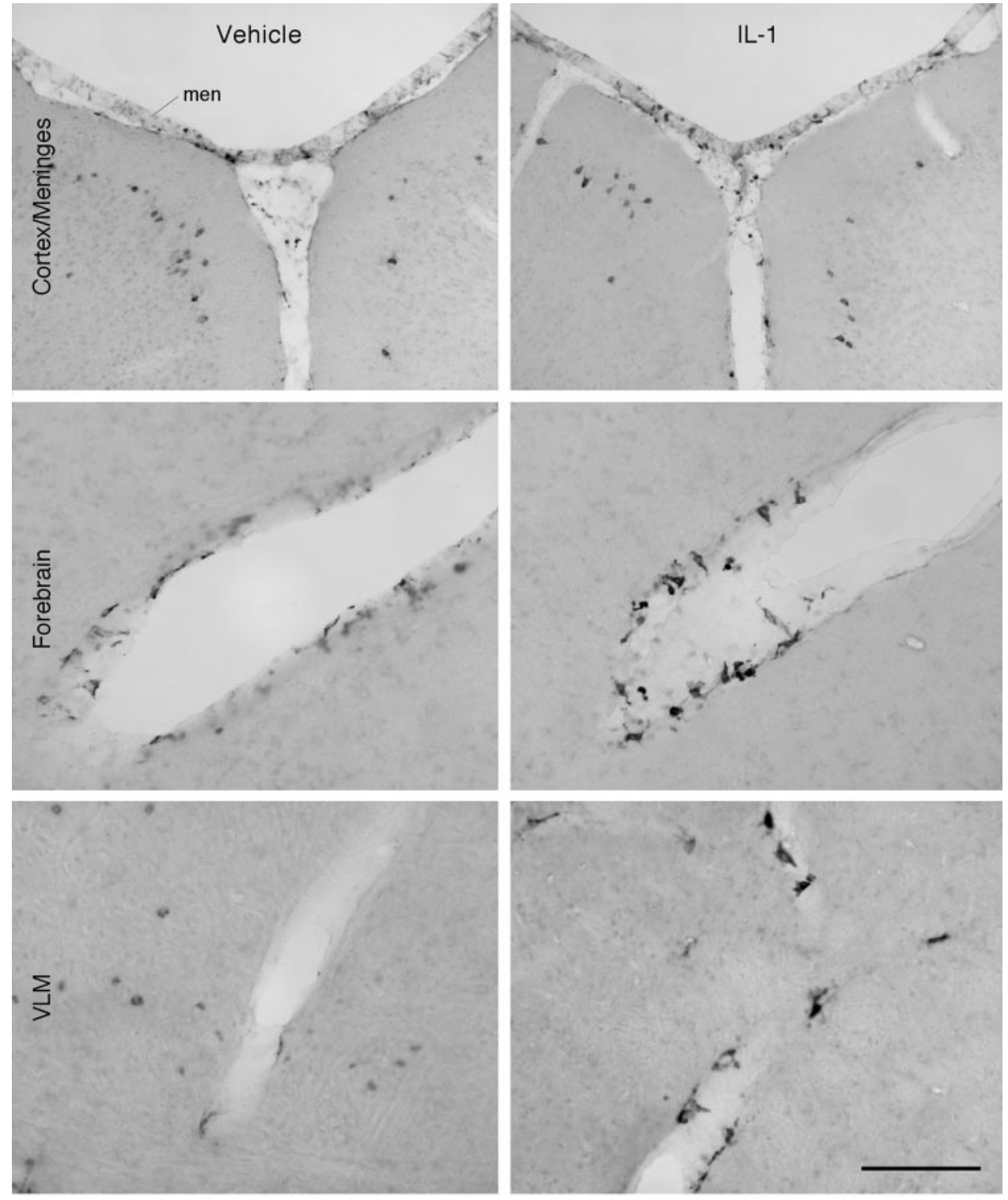

Figure 4. Immunoreactive COX-2 expression in the brain. Bright-field images of COX-2-ir cells in the isocortex and meninges (top) and cells associated with the vasculature in the forebrain (middle) and medulla (bottom), from rats killed $4 \mathrm{hr}$ after vehicle (left) or IL-1 injection (right). In agreement with findings at the mRNA level, constitutive COX-2-ir is seen within some cortical neurons and, at lower levels, in the meninges and perivascular regions. At $4 \mathrm{hr}$ after IL-1 $(1.87 \mu \mathrm{g} / \mathrm{kg})$ treatment, a clear increase in the number and staining intensity of COX-2-positive cells is seen within the meninges and perivascular regions, but not in neurons. Scale bar, $100 \mu \mathrm{m}$. distinct morphologies: a multipolar/polygonal form like that seen in response to IL-1, and presumed to conform to ED2-positive perivascular cells, and a distinctly round shape suggestive of nuclear staining. Cells exhibiting the rounded form were more closely and consistently associated with the vascular wall than presumed perivascular cells and were clearly the dominant cell type that exhibited induced COX-2 expression in rats treated with a high dose of LPS.

Localization of markers to identified endothelial cells has proven difficult because of their irregular and elongated forms, which blend continuously with one another, but SCLM images from rats treated with $100 \mu \mathrm{g}$ LPS suggest that the round COX2-ir can be localized in part to elements expressing RECA-1-ir, a rat brain endothelial cell antigen (Fig. 9). Material from LPSinjected animals contained multipolar/polygonal-shaped COX2-ir cells that did not express the RECA-1-ir (Fig. 9, arrow) but could be costained for ED2-ir (data not shown). Despite the distinctly different appearance of COX-2- and RECA-1-labeled elements, rounded profiles did frequently exhibit areas of overlap of the two markers near their periphery, supporting their identification as endothelial cells (Fig. 9, arrowhead).
This conclusion was supported by the results of immunoelectron microscopic localization of COX-2-ir in four rats treated with $100 \mu \mathrm{g} / \mathrm{kg}$ LPS (Fig. 10). In addition to labeled cells that conformed in morphology and location to IL-1-sensitive perivascular cells, numerous clear examples of endothelial cells that contained COX-2 reaction product with a discretely perinuclear localization were evident in this material.

Finally, to glean a clearer sense of the sensitivity of perivascular and endothelial cells to distinct immune challenge models, comparisons were undertaken of the extent of labeling of the two cell types as a function of the dose of IL-1 or LPS in groups of three to six animals each. To provide a basis for comparing the two challenges, induced expression of Fos-ir in the PVH was monitored as an independent index of the strength of the treatments. Rats treated with graded doses of IL-1 (1.87, 10, or 30 $\mu \mathrm{g} / \mathrm{kg}$ ) displayed dose-related induction of COX-2 expression of vascular cells. Over this range of doses, these appeared on morphological grounds to conform exclusively to perivascular cells (Fig. 11). Although LPS also clearly provoked dose-related COX-2 expression, the two cell types displayed distinct thresholds (Fig. 12). Thus, $0.1 \mu \mathrm{g} / \mathrm{kg}$ of LPS resulted in labeling only of 

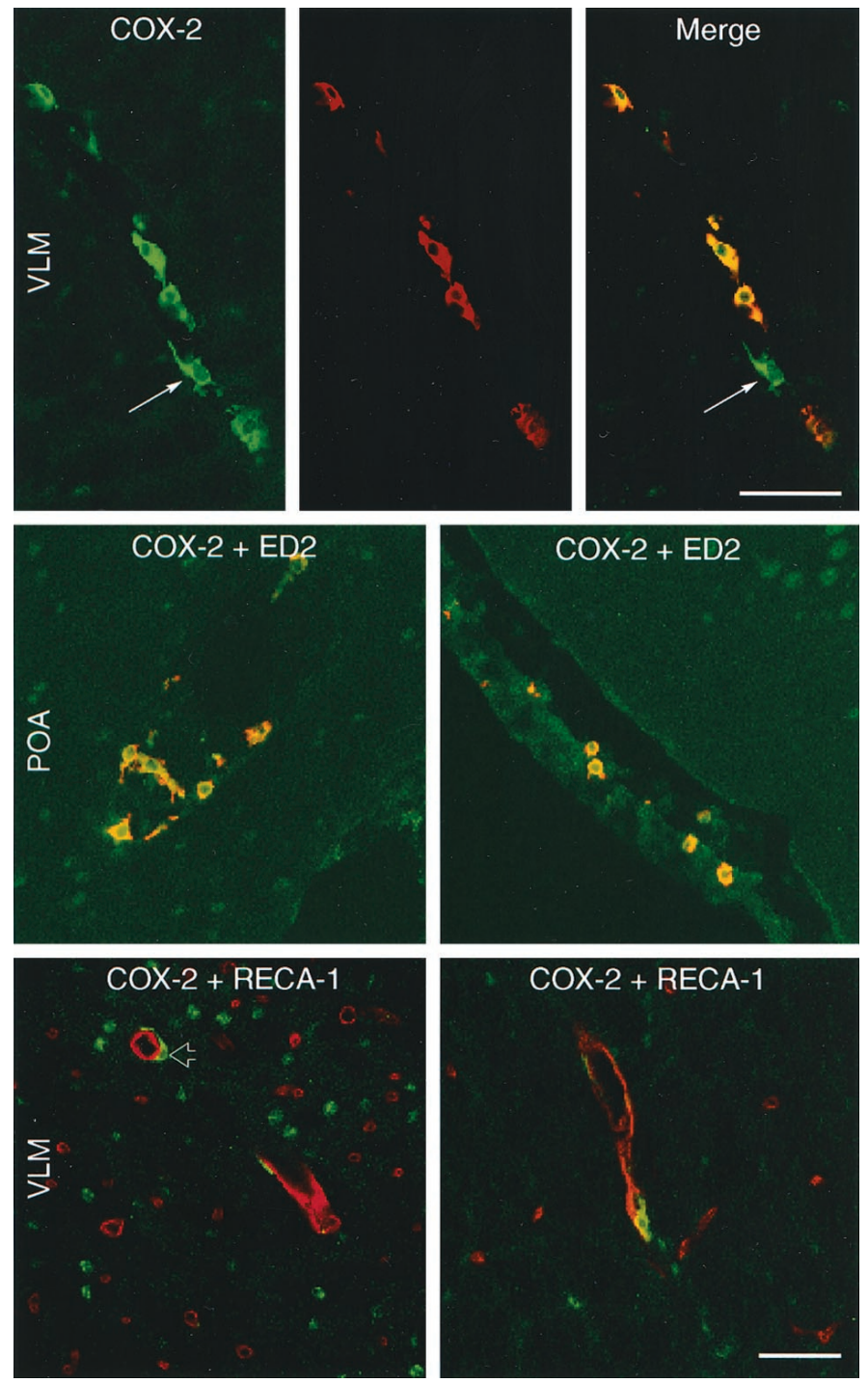

Figure 5. IL-1-induced COX-2 expression in perivascular cells. SCLM images showing dual immunostaining for COX-2 (green) and a marker for perivascular cells/macrophages (ED2, red, top and middle panels) or endothelial cells (RECA-1, red, bottom panels) in blood vessels in the medulla (top and bottom panels) or forebrain (middle panel). Results of dual immunolabeling of material from IL-1-challenged rats revealed that very nearly all COX-2-ir cells also stained positively for the ED2 antigen, suggesting that they may be considered perivascular cells as defined by Graeber et al. (1989). COX-2-ir was never found to colocalize with the endothelial marker RECA-1 (bottom panel), suggesting that endothelial cells do not manifest substantial COX-2 expression in this paradigm. The yellow color in the top right and middle two panels is from merged confocal images and represents a positive signal for both COX-2-ir and ED2-ir. The arrow indicates a single COX-2-positive, ED2-negative cell. The open arrow indicates a COX-2-positive cell immediately adjacent to a RECA-1-positive vessel. Scale bars, $50 \mu \mathrm{m}$. POA, Pre-optic area.

multipolar/polygonal-shaped cells. At $2 \mu \mathrm{g} / \mathrm{kg}$, a dose that provoked Fos induction in the PVH whose strength $(2034 \pm 121$ Fos-ir cells) most closely approximated that seen in response to high doses of IL-1 (2156 \pm 191 Fos-ir cells), the response profile included mainly multipolar/polygonal cells, although with a small proportion of weakly labeled round ones. Finally, with $100 \mu \mathrm{g} / \mathrm{kg}$ LPS, which elicited far more robust Fos induction in the PVH than was seen with any dose of IL-1 that we used, rounded COX-2-ir cells were clearly predominant, with labeled multipolar
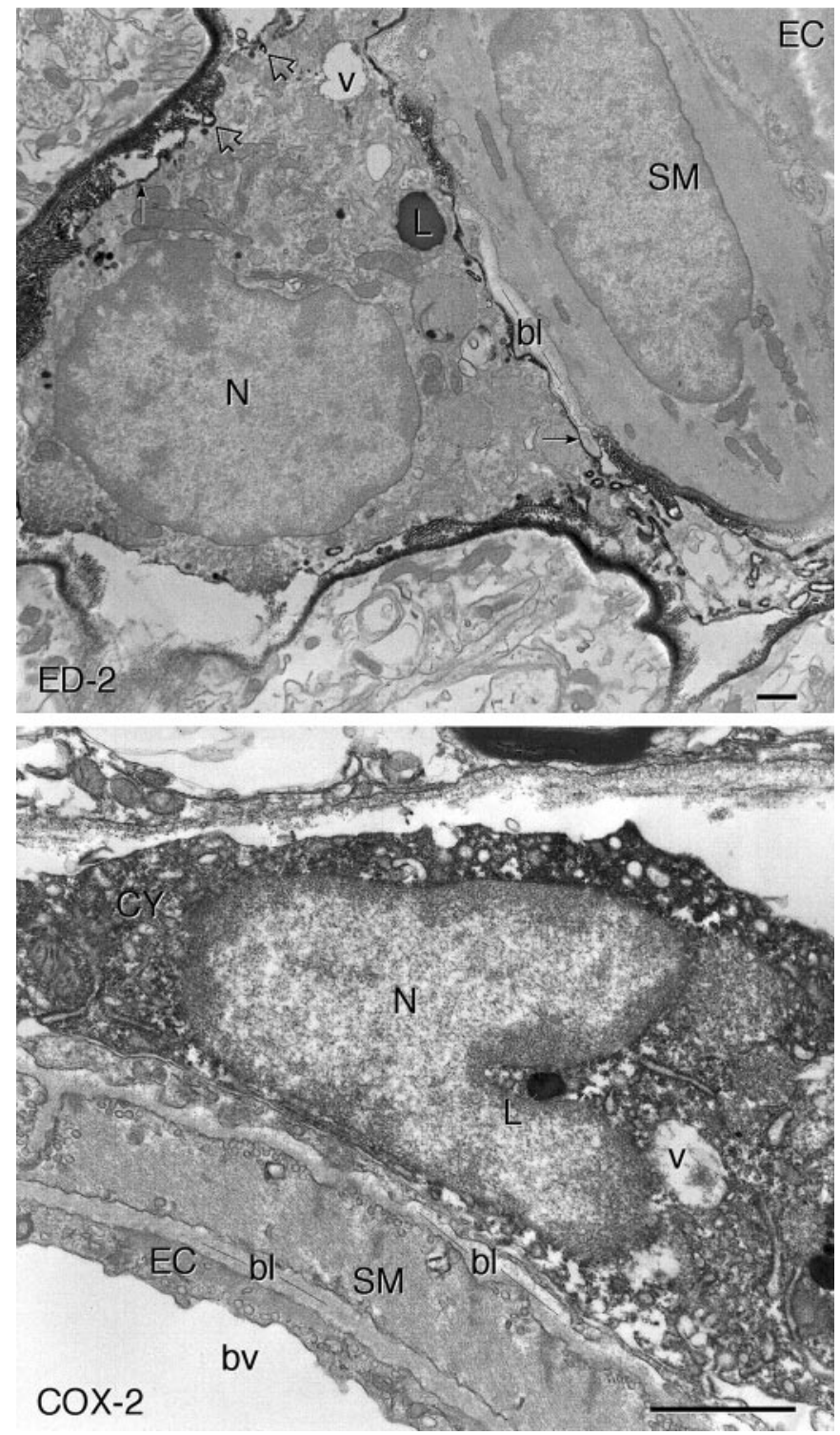

Figure 6. Fine structure of ED2-ir and COX-2-ir perivascular cells Electron micrographs showing pre-embedding immunolabeling for ED2 (top panel) and COX-2 (bottom panel) near blood vessels in the medulla of a rat treated with IL-1 $(1.87 \mu \mathrm{g} / \mathrm{kg})$. The ED2 antiserum recognizes a surface antigen, and the reaction product (black arrows) outlines a cell in a perivascular location, adjacent to a smooth muscle cell $(S M)$. The arrowheads indicate reaction product associated with membrane-bound vacuoles. COX-2 immunoreactivity is distributed diffusely within the cytoplasm $(C Y)$ of a cell of similar morphology and location. It also appears to be enclosed within a basal lamina, consistent again with the perivascular cell designation. $E C$, Endothelial cell; $b l$, basal lamina; $L$, lysosome; $N$, nucleus; $v$, vacuole; $b v$, blood vessel. Scale bars, $1 \mu \mathrm{m}$.

cells appearing at a density roughly comparable to that seen in response to lower $(2 \mu \mathrm{g} / \mathrm{kg})$ dosage levels.

Quantitative comparisons of the percentage of COX-2-positive cells that costained for ED2-ir were made in series through the ventrolateral medulla as a function of treatment status. Groups of rats treated with $1.87,10$, or $30 \mu \mathrm{g} / \mathrm{kg}$ of IL-1 and $0.1 \mu \mathrm{g}$ of LPS had values ranging between $92 \pm 9$ and $100 \pm 0 \%$. In animals treated with $2 \mu \mathrm{g} / \mathrm{kg}$ LPS, this value was $70 \pm 9 \%$, and in rats treated with the highest dose $(100 \mu \mathrm{g} / \mathrm{kg})$, only $13 \pm 2 \%$ of the COX-2-labeled cells also expressed ED2-ir, with the remainder 

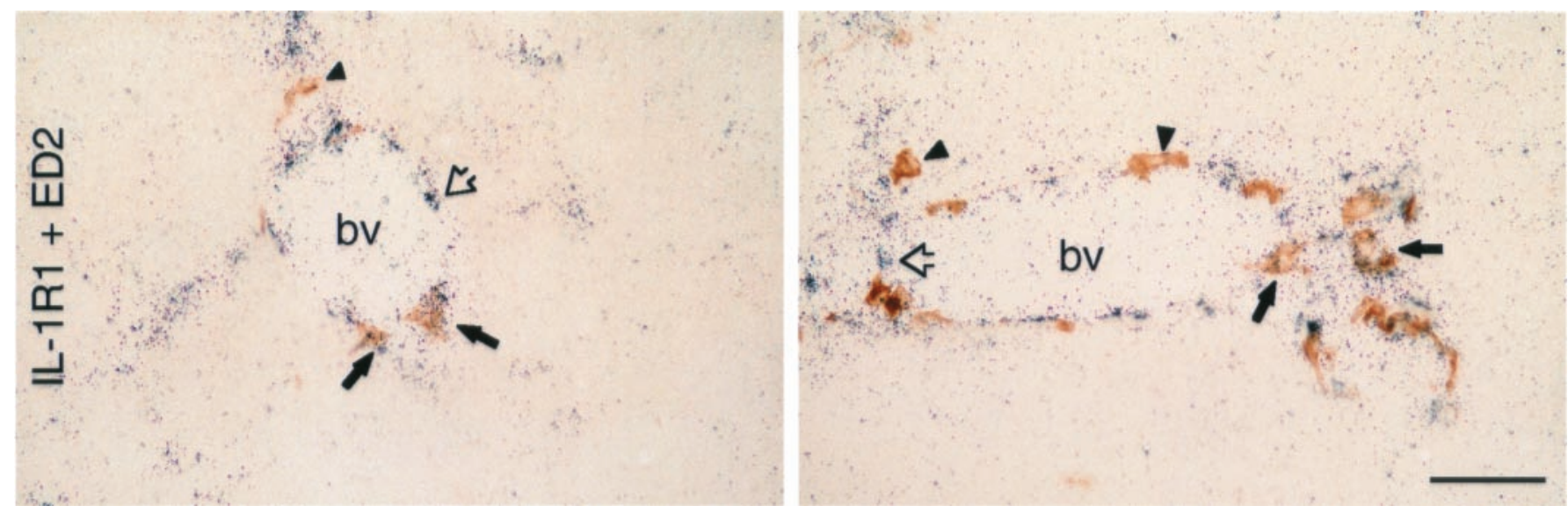

Figure 7. Dual localization of ED2-ir and IL-1R1 mRNA. Bright-field photomicrographs of sections from untreated rats, showing the distribution of ED2-ir perivascular cells (brown) and IL-1R1 mRNA (black grains) around blood vessels in the ventrolateral medulla. Black arrows indicate cells expressing both markers. Not all receptor-bearing cells are ED2 positive (open arrows), suggesting that other cell types associated with the vasculature (i.e., endothelial or other vasculature-associated cell types) may exhibit IL-1 sensitivity, and not all ED2-positive cells appear to express the receptor (black arrowheads), suggesting some heterogeneity among ED2-positive perivascular cells. Scale bar, $50 \mu \mathrm{m}$.
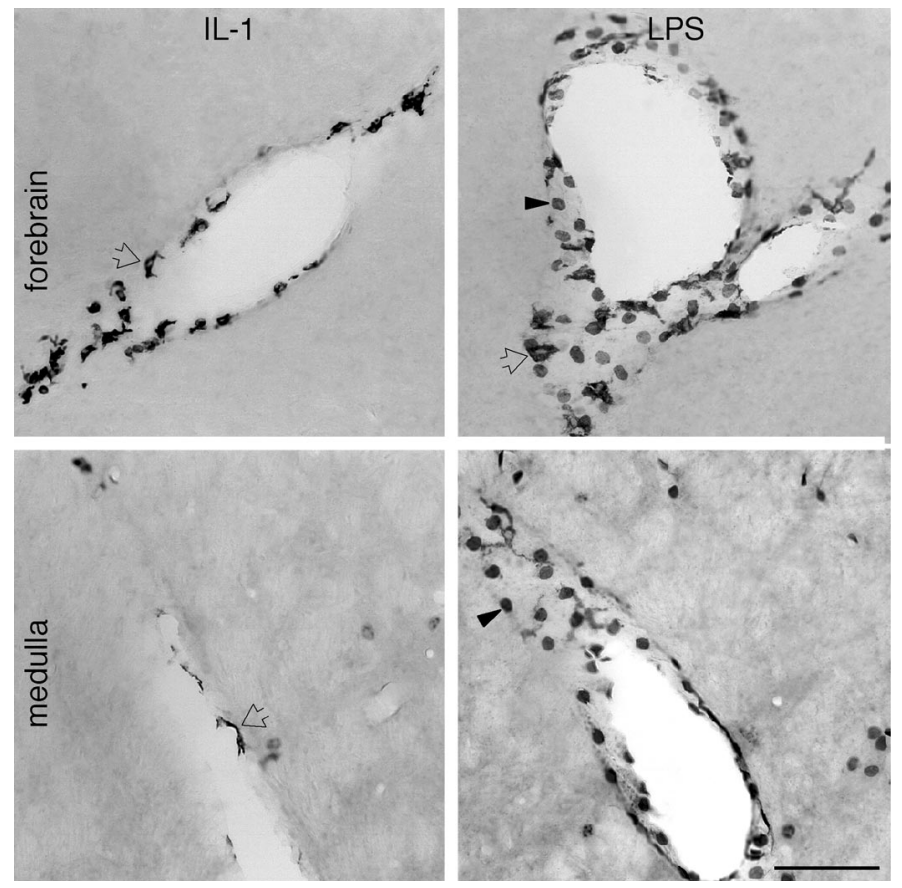

Figure 8. Immunoreactive COX-2 expression in vasculature-associated cells in response to IL-1 versus LPS. Bright-field images of COX-2-ir cells associated with the vasculature in the forebrain (top) and medulla (bottom) from rats killed $4 \mathrm{hr}$ after intravenous injection of IL-1 $(1.87 \mu \mathrm{g}$, left $)$ or LPS $(100 \mu \mathrm{g} / \mathrm{kg}$, right $)$. As with IL-1, at $4 \mathrm{hr}$ after LPS treatment, a clear increase in the number and staining intensity of COX-2-positive cells is seen within perivascular regions throughout the brain. However, the predominant cell types manifesting enzyme expression after each treatment are morphologically distinct. COX-2-positive polygonal/multipolar cells (open arrows) are seen in response to each treatment and exclusively in material from IL-1-treated animals. COX-2-positive round cells (arrowheads) are evident only in rats treated with LPS. Scale bar, $100 \mu \mathrm{m}$.

exhibiting the rounded appearance presumably indicative of enzyme expression in endothelia.

\section{DISCUSSION}

Here we provide additional evidence to support the view that prostanoid synthesis is induced within the brain in response to a systemic IL-1 challenge and is required for activation of HPA control circuitry in this paradigm. In addition, we offer a basis for reconciling discrepant findings in the literature bearing on the identity of the vascular cell type(s) that manifest(s) induced prostanoid synthesis in two widely used immune challenge paradigms. Our findings identify perivascular cells as the dominant, if not sole, seat of COX-2 induction seen in response to a range of IL-1 treatment conditions and low doses of LPS, whereas such engagement of endothelial cells requires more strenuous LPS challenges. This raises intriguing questions and possibilities concerning the transduction of immune signals at the blood-brain interface.

Previous work has shown that pretreatment with systemic indomethacin attenuates a range of centrally mediated acute phase responses induced by IL-1, including secretory and biosynthetic activities of the HPA axis (Katsuura et al., 1988; Morimoto et al., 1989; Watanabe et al., 1990; Ericsson et al., 1997; Lacroix and Rivest, 1997). Because of the capacity of activated immune cells to synthesize prostaglandins, this left open the question of whether a peripheral versus central site of action was responsible for such effects. In the present study, we demonstrate that central administration of indomethacin reduces to control levels IL-1induced activational responses both in the hypothalamic site of $\mathrm{CRF}$ production for HPA axis regulation ( $\mathrm{PVH}$ ) and in a relevant afferent cell group on whose integrity the hypothalamic response depends (ventrolateral medulla). This supports the view that induced synthesis of prostaglandins within the brain is required for the activation of HPA control systems in response to systemic (intravenous) IL-1.

In general terms, our findings on the basal and IL-1-stimulated distribution of COX-2 expression in brain are compatible with previous reports on this topic (Breder et al., 1992; Elmquist et al., 1997a; Lacroix and Rivest, 1998). Thus, in the unstimulated condition, COX-2 is expressed mainly within neurons of the hippocampal formation, and olfactory and isocortex, and in unidentified elements of the area postrema. Enzyme expression is also detectable in the leptomeninges and vasculature, albeit at low levels, raising questions about whether basal expression of the enzyme and its products are sufficient to participate in acute phase responses to IL-1 or endotoxin challenges, such as in- 

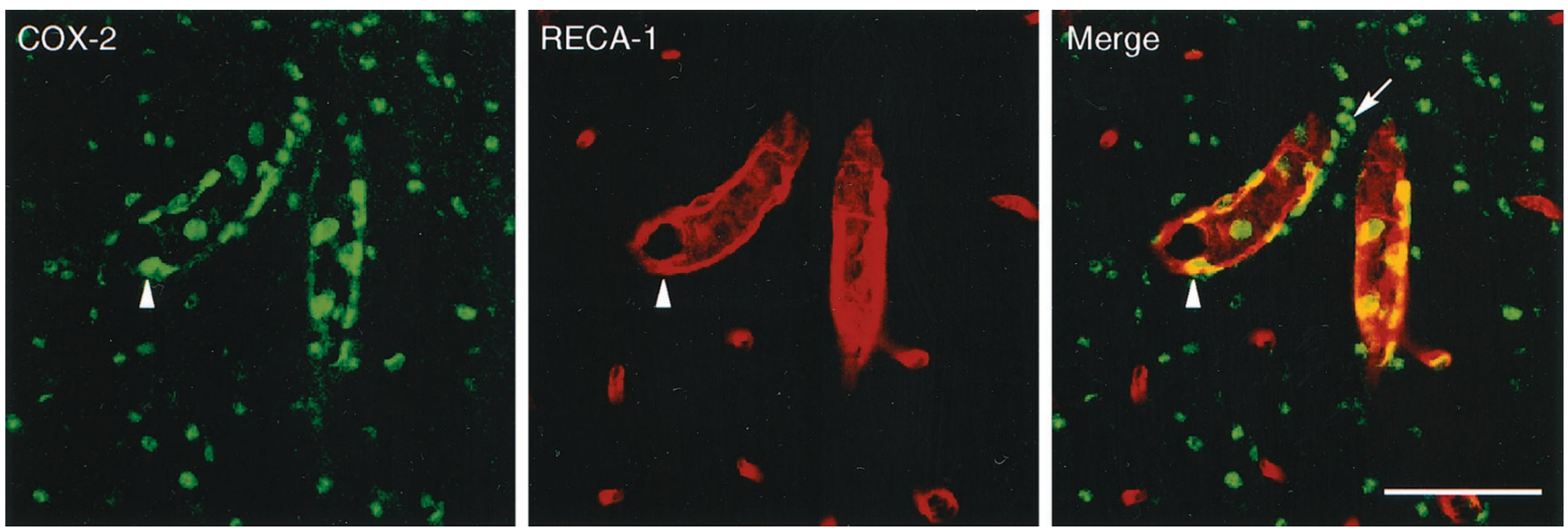

Figure 9. LPS-induced COX-2 expression in vasculature-associated cells. SCLM images show dual immunostaining for COX-2 (green, left) and RECA-1, a marker for endothelial cells (red, middle), in blood vessels in the forebrain. Results of dual immunolabeling of material from rats challenged with $100 \mu \mathrm{g} / \mathrm{kg}$ LPS revealed that many round COX-2-ir cells coexpress the endothelial marker RECA-1 (right panel). Another population of COX-2-ir cells, polygonal or multipolar in form, stained positively for the ED2 antigen (data not shown) in LPS-treated rats. The yellow color in the merged image (right) represents a positive signal for both markers and is consistent with a perinuclear distribution of COX-2-ir in activated endothelial cells. Arrowhead indicates a COX-2- and RECA-1-positive cell. Arrow indicates a multipolar COX-2-positive cell that did not express RECA-1. Scale bar, $50 \mu \mathrm{m}$.

Figure 10. Fine structure of LPS-sensitive vasculature-associated cells. Electron micrographs showing pre-embedding immunoperoxidase labeling for COX-2 in vasculatureassociated cells in the forebrain of a rat treated with $100 \mu \mathrm{g} / \mathrm{kg}$ LPS. COX-2-ir is distributed diffusely within the cytoplasm of a cell (top panel, dotted line) that is not an integral component of the vascular wall, is segregated from the brain parenchyma by a basal lamina, and displays morphological features similar to ED2-positive perivascular cells. The bottom panels show examples of COX-2-ir within endothelial cells. Note the perinuclear distribution of the reaction product, consistent with the light-level appearance of COX-2-ir in this cell type. Arrows indicate positive labeling for COX-2. $N$, Nucleus; $b l$, basal lamina; $E C$, endothelial cell; $b v$, blood vessel. Scale bar, $1 \mu \mathrm{m}$.
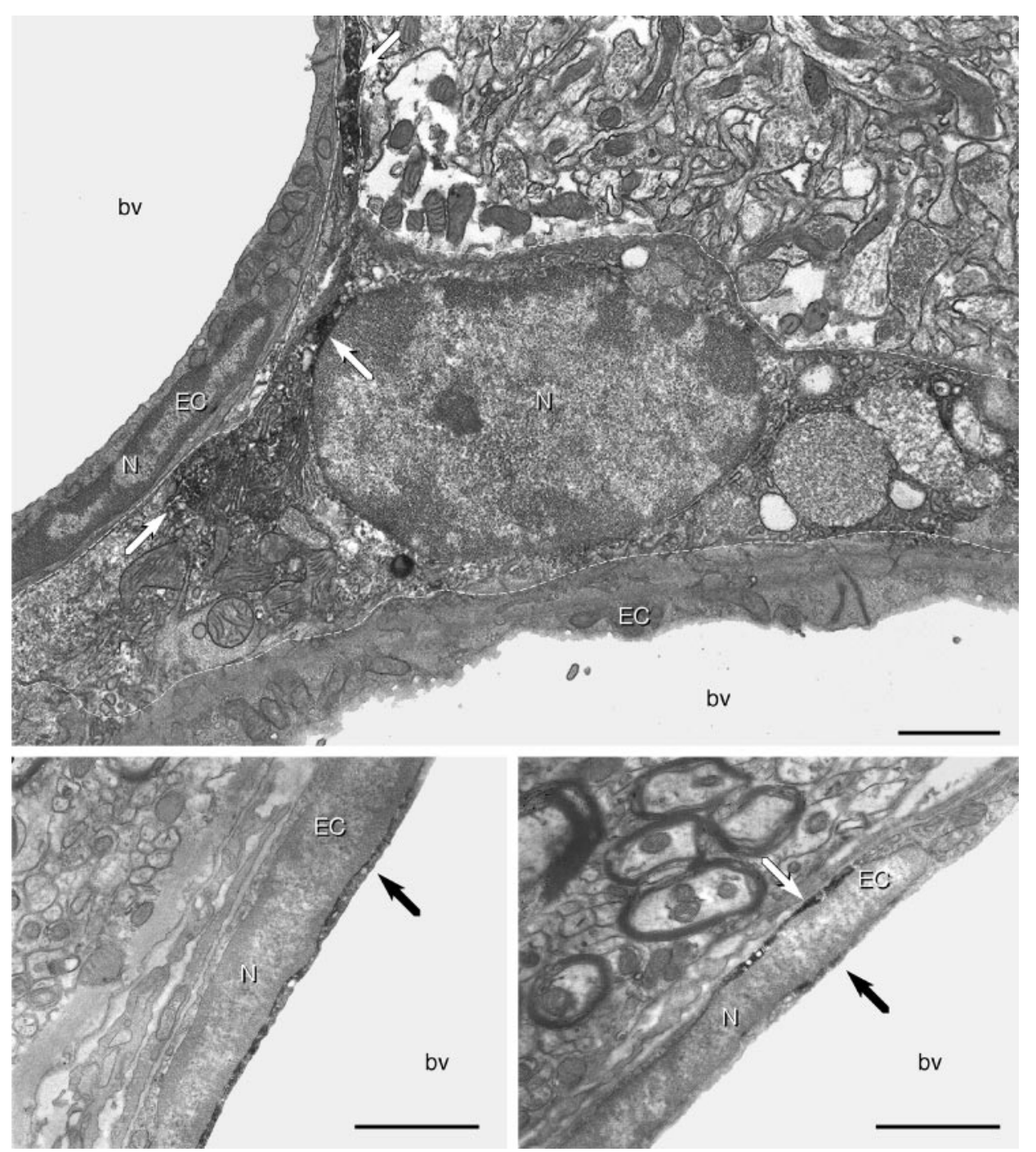

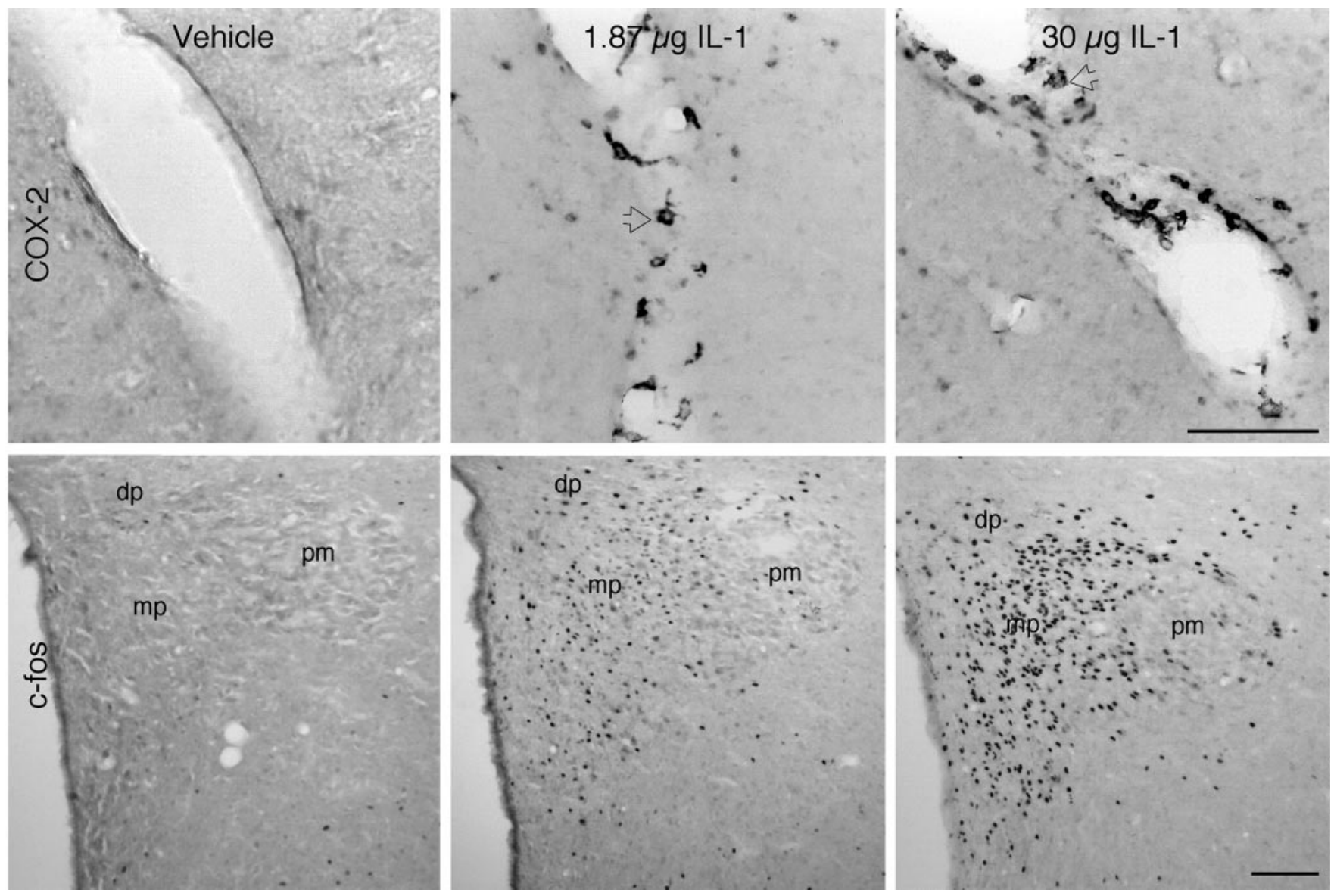

Figure 11. Vascular COX-2-ir induction as a function of IL-1 dose. Bright-field images show blood vessels stained for COX-2 (top row) or the PVN labeled for Fos-ir (bottom row), from rats given vehicle (left panels), $1.87 \mu \mathrm{g} / \mathrm{kg}$ (middle panels), or $30 \mu \mathrm{g} / \mathrm{kg}$ IL-1 (right panels). To provide an index of the strength of the stimulus, Fos-ir induction in the PVH seen in response to the same treatments is shown (bottom row). In vehicle-treated rats, few to no COX-2-ir cells are found in association with blood vessels (top left), and Fos expression is not detected within the PVH (bottom left). As documented previously, $1.87 \mu \mathrm{g} / \mathrm{kg}$ doses of IL-1 stimulate COX-2-expression within polygonal or multipolar cells presumed to conform to ED2-positive perivascular cells (top, middle, open arrows); moderate Fos-ir induction is localized principally to the medial parvocellular $(\mathrm{mp})$ part of the PVH, with lesser involvement of the dorsal parvocellular $(\mathrm{dp}$ )and posterior magnocellular ( $\mathrm{pm}$ ) subdivisions (bottom, middle). The $30 \mu \mathrm{g} / \mathrm{kg}$ IL-1 dose produces more robust Fos induction in the PVH (bottom, right), comparable to that seen in response to $2 \mu \mathrm{g} / \mathrm{kg}$ LPS. Nevertheless, only elements exhibiting perivascular cell morphology manifest COX-2-ir in response to the higher IL-1 dose (top, right). Scale bar, $100 \mu \mathrm{m}$.

creased ACTH secretion, that can occur within minutes after administration. Our results are also in line with numerous reports of marked increases in the number of meningeal and vascular, but not neuronal, cells that exhibit COX-2 expression after systemic IL-1 or LPS. However, the particular vascular cell type(s) to which this response is localized has remained a point of contention (Rivest, 1999).

Elmquist and colleagues (1997a) found after intravenous injection of 5 or $125 \mu \mathrm{g} / \mathrm{kg}$ LPS that most vascular COX-2 expression could be localized to perivascular microglia, of a form similar to the perivascular cells seen in our material. Another group has reported endothelial cells to be the dominant site of COX-2 induction in rats given $30 \mu \mathrm{g} / \mathrm{kg}$ IL-1 or $100 \mu \mathrm{g} / \mathrm{kg}$ LPS via the intraperitoneal route (Cao et al., 1996; Matsumura et al., 1998). A third group found evidence for a predominant localization of LPS-induced COX-2 expression in endothelia, with substantially lesser involvement of perivascular cells, independent of the dose and route of endotoxin administration (Quan et al., 1998). A similar conclusion was reached in a recent study examining PGE synthase expression in response to intravenous IL-1 using a nonselective marker for vascular-associated cells (Ek et al., 2001).
Our results are clear in indicating that, over the range of doses examined, IL-1 evokes COX-2 expression selectively within cells that on the basis of morphology, location, and expression of the ED2 macrophage differentiation antigen conform to perivascular cells. LPS, by contrast, can induce COX-2 expression in both perivascular and endothelial cells in a dose-dependent manner, with the former exhibiting the lower threshold to expression. We cannot exclude the possibility that an extremely high dose of IL-1 might provoke enzyme expression in endothelia, although it is worthy of note that all the doses of IL-1 used here are sufficient to elicit activation of the PVH and associated circuitry, increased levels of CRF mRNA, and HPA secretory responses (Rivier et al., 1989; Ericsson et al., 1994). Such considerations bear directly on the question of the extent to which IL-1 may participate in provoking endothelial cells to synthesize COX-2. LPS induces a cascade of cytokine production that includes IL-6, IL-1, and tumor necrosis factor- $\alpha$, with the latter two being capable of independently inducing vascular COX-2 expression (Lacroix and Rivest, 1998; Blais and Rivest, 2001; Mark et al., 2001).

The basis for the disparities between the present and past treatments of the topic are not entirely clear. It is possible that the 

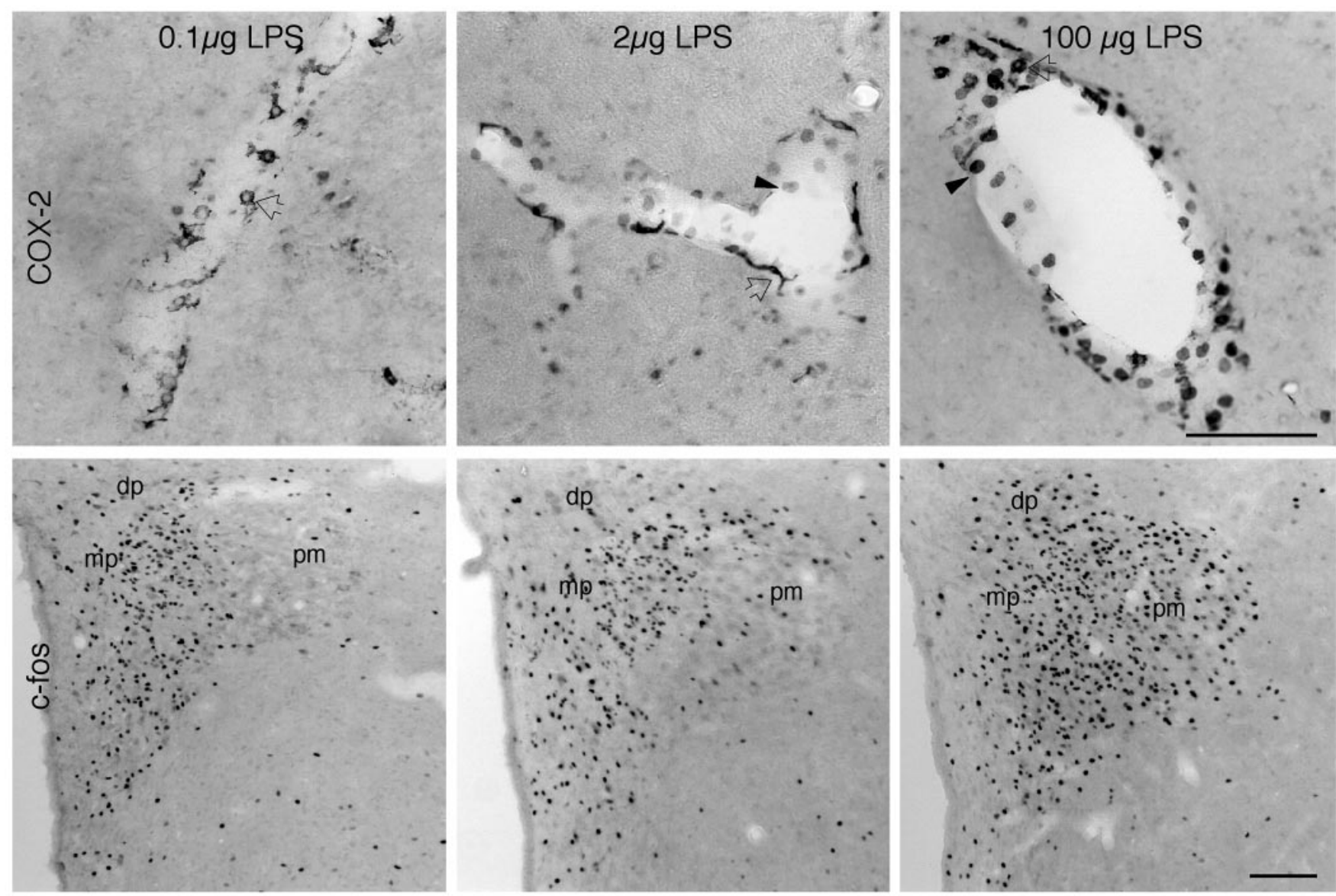

Figure 12. Strength and locus of COX-2 induction as a function of LPS dose. Bright-field images show vessels stained for COX-2 (top row) from rats given $0.1 \mu \mathrm{g} / \mathrm{kg}$ (left), $2 \mu \mathrm{g} / \mathrm{kg}$ (middle), or $100 \mu \mathrm{g} / \mathrm{kg}$ (right) LPS. In rats treated with $0.1 \mu \mathrm{g} / \mathrm{kg}$ LPS (left), only cells exhibiting perivascular cell morphology manifest COX-2-ir (left, open arrows). Even this low dose provokes significant activation of neurons within the PVH, especially its CRF-rich medial parvocellular ( $\mathrm{mp}$ ) subdivision. In response to the $2 \mu \mathrm{g} / \mathrm{kg}$ LPS dose (middle), both polygonal/multipolar (open arrows) and round-shaped cells (closed arrowheads) exhibit COX-2-ir, suggesting involvement of both perivascular and endothelial cells. Fos induction under this condition is marginally increased, with greater involvement of the dorsal parvocellular $(d p)$ and posterior magnocellular $(p m)$ aspects of the PVH. The $100 \mu \mathrm{g} / \mathrm{kg}$ LPS dose (right) also provokes COX-2-ir expression in both polygonal/multipolar (open arrows) and round (arrowheads) cells, whose number and staining intensity are enhanced. Fos induction in the PVH is most robust under this condition and distributed uniformly throughout all subregions of the nucleus. Scale bar, $100 \mu \mathrm{m}$.

generally higher doses of LPS used in previous studies may have resulted in activation of a sufficiently large population of endothelia as to allow perivascular cells to be overlooked or underestimated. In addition, there is evidence that ED2 expression in perivascular cells may be acutely diminished after exposure to higher doses of LPS, thereby confounding their identification (Mato et al., 1998). Other potential contributors include differences in the route of LPS administration (intraperitoneal vs intravenous), which could result in presentation of distinct complements and concentrations of cytokines to the cerebral vasculature. Moreover, aforementioned difficulties in localizing multiple markers to endothelial cells has frequently required modification of conventional fixation and tissue processing protocols (Cao et al., 1996; Elmquist et al., 1997a; Matsumura et al., 1998), which could make them more subject to artifact. In any event, we suggest that the consistency of the outcomes achieved in comparing directly IL-1 and LPS effects over a range of doses should serve to reconcile disparate findings in this literature.

The literature bearing on the nomenclature and identity of vascular-associated cells other than endothelia is confusing and sometimes conflicting. Because the cells in this study stain for
ED2 and not endothelial or macroglial markers, and because their morphology is distinct from pericytes or endothelial cells, and because they are not integral components of the vascular wall, we follow Graeber and Streit (1990) in referring to them as "perivascular cells." Perivascular cells are believed to derive from bone marrow progenitors that take up residence in the perivascular spaces and meninges of the brain during early development and come to express high levels of major histocompatibility complex II antigens and thus play a role in antigen recognition and presentation in the CNS (Hickey and Kimura, 1988; Gehrmann et al., 1995). In addition, they are phagocytic, contain dense lysosomal bodies, and depending on their location may (Graeber et al., 1989) or may not be completely enclosed by a basal lamina (Kida et al., 1993; Angelov et al., 1998). In line with the results of Bechmann et al. (2001), we found the ED2-positive cells to be located between the second and third basement membranes or in the space separating the endothelial cell/pericyte layer from the glia limitans (Figs. 6, 10). It worthy to note that ED2-positive cells associated with the vasculature and meninges are readily detectable in control animals, and their numbers do not appear to change acutely after IL-1 treatment. Although recent evidence 
indicates that immune insults can foster migration of immune cells into brain (Bohatschek et al., 2001), the time course of such responses (12 hr to days) is incompatible with their contributing substantially to the ED2 population observed over the 2-4 hr time points after treatment analyzed here. Clearly, more needs to be known about these cells, including whether they may represent an intermediate stage in the differentiation of other cell types. The findings that indomethacin, which is not believed to cross the blood-brain barrier, can block IL-1-induced activation of HPA control circuitry when given either intravenously (Ericsson et al., 1997) or intracerebroventricularly suggests that these cells may occupy the unique position of being readily accessible to both the systemic and cerebral ventricular circulations. This notion is also supported by the observation that these cells phagocytize tracers and macromolecules introduced into either the CSF or the systemic circulation (Kida et al., 1993, Mato et al., 1996).

Both IL-1 and LPS are of sufficient size as to preclude their ability to directly access the CNS in biologically significant concentrations. Mounting evidence from many laboratories supports the hypothesis that secondary signaling molecules such as prostanoids, nitric oxide, or locally produced cytokines themselves synthesized by cells at the barriers between the brain and its fluid environments, play a crucial role in transducing circulating cytokine signals (Kilbourn and Belloni, 1990; Schindler et al., 1990; McCarron, 1992; van Dam et al., 1992). Although our results support a prominent role for perivascular cells in this regard, details of the transduction mechanism(s) are lacking. We have demonstrated that at least some perivascular cells express IL-1R1 mRNA but are unaware of evidence that speaks directly to the question of whether they can be accessed directly by circulating macromolecules, including cytokines. Alternatively, IL-1 may bind initially to endothelial cells, which also bear IL-1 receptors (van Dam et al., 1996) (Fig. 7), and in turn release a paracrine factor to activate prostanoid production and release by local perivascular cells. Similarly, LPS may be capable of activating directly endothelial and perivascular cells, because vascular localizations of CD14 mRNA have been reported (Lacroix et al., 1998), or its effects may be attributable to its capacity to provoke cytokine release. In any event, prostanoids are then presumed to diffuse through the extracellular space to interact with parenchymal elements bearing cognate receptors. For example, prostanoid receptor expression of both EP3 and EP4 has been localized to IL-1-sensitive medullary catecholamine neurons (Zhang and Rivest, 1999; Ek et al., 2000). Our working hypothesis posits that activation of these populations leads to engagement of CRFexpressing PVH neurons by way of well known direct axonal projections (Cunningham et al., 1990), an idea supported by the capacity of medullary PGE2 injections to discretely stimulate both local aminergic neurons and their hypothalamic targets (Ericsson et al., 1997).

In summary, our findings suggest that ED2-positive perivascular cells are positioned to play a privileged role in immune-tobrain communication by virtue of their low threshold to prostanoid synthesis provoked by increased circulating levels of either IL-1 or LPS. Endothelial cells are also clearly capable of LPSinduced COX-2 expression, although with lesser sensitivity. Recent evidence to indicate that perivascular cells can be ablated with at least some selectivity by exploiting their susceptibility to ionizing radiation (Priller et al., 2001) or their capacity to phagocytize (clondronate-laden) liposomes introduced into the ventricular system (Polfliet et al., 2001a,b, 2002) should allow more penetrating assessment of the role of this cell type in CNS responses to immune and inflammatory insults.

\section{REFERENCES}

Abercrombie M (1946) Estimation of nuclear populations from microtome populations from microtome sections. Anat Rec 94:239-247.

Angelov DN, Walther M, Streppel M, Guntinas-Lichius O, Neiss WF (1998) The cerebral perivascular cells. Adv Anat Embryol Cell Biol 147:1-87.

Bechmann I, Kwidzinski E, Kovac AD, Simburger E, Horvath T, Gimsa U, Dirnagl U, Priller J, Nitsch R (2001) Turnover of rat brain perivascular cells. Exp Neurol 168:242-249.

Besedovsky H, Del Rey A, Sorkin E, Dinarello CA (1986) Immunoregulatory feedback between interleukin-1 and glucocorticoid hormones. Science 233:652-654.

Bittencourt JC, Sawchenko PE (2000) Do centrally administered neuropeptides access cognate receptors?: an analysis in the central corticotropin-releasing factor system. J Neurosci 20:1142-1156.

Blais V, Rivest S (2001) Inhibitory action of nitric oxide on circulating tumor necrosis factor-induced NF-kappaB activity and COX-2 transcription in the endothelium of the brain capillaries. J Neuropathol Exp Neurol 60:893-905.

Blatteis CM, Sehic E (1997) Fever: how may circulating pyrogens signal the brain? News Physiol Sci 12:1-9.

Bohatschek M, Werner A, Raivich G (2001) Systemic LPS injection leads to granulocyte influx into normal and injured brain: effects of ICAM-1 deficiency. Exp Neurol 172:137-152.

Breder CD, Smith WL, Raz A, Masferrer J, Seibert K, Needleman P, Saper CB (1992) Distribution and characterization of cyclooxygenase immunoreactivity in the ovine brain. J Comp Neurol 322:409-438.

Cao C, Matsumura K, Yamagata K, Watanabe Y (1996) Endothelial cells of the rat brain vasculature express cyclooxygenase-2 mRNA in response to systemic interleukin-1B: a possible site of prostaglandin synthesis responsible for fever. Brain Res 733:263-272.

Chan RKW, Brown ER, Ericsson A, Kovács KJ, Sawchenko PE (1993) A comparison of two immediate-early genes, c-fos and NGFI-B, as markers for functional activation in stress-related neuroendocrine circuitry. J Neurosci 13:5125-5138.

Cunningham Jr ET, Bohn MC, Sawchenko PE (1990) Organization of adrenergic inputs to the paraventricular and supraoptic nuclei of the hypothalamus in the rat. J Comp Neurol 292:651-667.

Dantzer R (1994) How do cytokines say hello to the brain? Neural versus humoral mediation. Eur Cytokine Network 5:271-273.

Dantzer R, Bluthe RM, Gheusi G, Cremona S, Laye S, Parnet P, Kelley KW (1998) Molecular basis of sickness behavior. Ann NY Acad Sci 856:132-138.

Dijkstra CD, Dopp EA, Joling P, Kraal G (1985) The heterogeneity of mononuclear phagocytes in lymphoid organs: distinct macrophage sunpopulations in the rat recognized by monoclonal antibodies ED1, ED2 and ED3. Immunology 54:589-599.

Dinarello CA (1984) Interleukin-1 and the pathogenesis of the acutephase response. N Engl J Med 311:1413-1418.

Dinarello CA (1988) Biology of interleukin-1. FASEB J 2:108-115.

Dinarello CA (1991) Interleukin-1 and interleukin-1 antagonism. Blood 77:1627-1652.

Duijvestijn AM, Van Goor H, Klatter F, Majoor GD, Van Bussel E, Van Breda Vriesman P (1992) Antibodies defining rat endothelial cells: RECA-1, a pan-endothelial cell-specific monoclonal antibody. Lab Invest 66:459-466.

Ek M, Arias C, Sawchenko P, Ericsson-Dahlstrand A (2000) Distribution of the EP3 prostaglandin E2 receptor subtype in the rat brain relationship to sites of interleukin-1-induced cellular responsiveness. J Comp Neurol 428:5-20.

Ek M, Engblom D, Saha S, Blomqvist A, Jakobsson PJ, EricssonDahlstrand A (2001) Pathway across the blood-brain barrier. Nature 410:430-431.

Elmquist JK, Breder CD, Sherin JE, Scammell TE, Hickey WF, Dewitt D, Saper CB (1997a) Intravenous lipopolysaccharide induces cyclooxygenase 2-like immunoreactivity in rat brain perivascular microglia and meningeal macrophages. J Comp Neurol 381:119-129.

Elmquist JK, Scammell TE, Saper CB (1997b) Mechanisms of CNS response to systemic immune challenge: the febrile response. Trends Neurosci 12:565-570.

Ericsson A, Sawchenko PE (1993) c-fos-Based functional mapping of central pathways subserving effects of interleukin 1 on the hypothalamo-pituitary-adrenal axis. Methods Neurosci 16:155-172.

Ericsson A, Kovács KJ, Sawchenko PE (1994) A functional anatomical analysis of central pathways subserving the effects of interleukin-1 on stress-related neuroendocrine neurons. J Neurosci 14:897-913.

Ericsson A, Liu C, Hart RP, Sawchenko PE (1995) Type 1 interleukin-1 receptor in the rat brain: distribution, regulation, and relationship to sites of IL-1-induced cellular activation. J Comp Neurol 361:681-698.

Ericsson A, Ek M, Wahlstrom I, Kovacs K, Liu C-L, Hart R, Sawchenko 
PE (1996) Pathways and mechanisms for interleukin-1 mediated regulation of the hypothalamo-pituitary-adrenal axis. In: Stress: molecular genetic and neurobiological advances (McCarty R, Aguilera G, Sabban E, Kvetnansky R, eds), pp 101-120. New York: Gordon and Breach.

Ericsson A, Arias C, Sawchenko PE (1997) Evidence for an intramedullary prostaglandin-dependent mechanism in the activation of stressrelated neuroendocrine circuitry by intravenous interleukin-1. J Neurosci 17:7166-7179.

Gehrmann J, Matsumoto Y, Kreutzberg GW (1995) Microglia: intrinsic immuneffector cell of the brain. Brain Res Rev 20:269-287.

Graeber MB, Streit WJ (1990) Perivascular microglia defined. Trends Neurosci 13:366.

Graeber MB, Streit WJ, Kreutzberg GW (1989) Identity of ED2positive perivascular cells in rat brain. J Neurosci Res 22:103-106.

Hickey W, Kimura H (1988) Perivascular microglia cells of the CNS are bone marrow derived and present antigen in vivo. Science 239:290-292.

Huang Q, Liu D, Majewski P, Schulte LC, Korn JM, Young RA, Lander ES, Hacohen N (2001) The plasticity of dendritic cell responses to pathogens and their components. Science 294:870-875.

Katsuura G, Gottschall PE, Dahl RR, Arimura A (1988) Adrenocorticotropin release induced by intracerebroventricular injection of recombinant human interleukin-1 in rats: possible involvement of prostaglandin. Endocrinology 122:1773-1779.

Kida S, Steart PV, Zhang E-T, Weller RO (1993) Perivascular cells act as scavengers in the cerebral perivascular spaces and remain distinct from pericytes, microglia and macrophages. Acta Neuropathol 85:646-652.

Kilbourn RG, Belloni P (1990) Endothelial cell production of nitrogen oxides in response to interferon gamma in combination with tumor necrosis factor, interleukin-1, or endotoxin. J Natl Cancer Inst 82:772-776.

Krueger JM, Obal F, Fang J (1999) Humoral regulation of physiological sleep: cytokines and GHRH. J Sleep Res 1:53-59.

Lacroix S, Rivest S (1997) Functional circuitry in the brain of immunechallenged rats: partial involvement of prostaglandins. J Comp Neurol 387:307-324.

Lacroix S, Rivest S (1998) Effect of acute systemic inflammatory response and cytokines on the transcription of the genes encoding cyclooxygenase enzymes (COX-1 and COX-2) in the rat brain. J Neurochem 70:452-466.

Lacroix S, Feinstein D, Rivest S (1998) The bacterial endotoxin lipopolysaccharide has the ability to target the brain in upregulating its membrane CD14 receptor within specific cellular populations. Brain Pathol 8:625-640.

Mark KS, Trickler WJ, Miller DW (2001) Tumor necrosis factor-alpha induces cyclooxygenase- 2 expression and prostaglandin release in brain microvessel endothelial cells. J Pharmacol Exp Ther 297:1051-1058.

Mato M, Ookawara S, Sakamoto A, Aikawa E, Ogawa T, Mitsuhashi U, Masuzawa T, Suzuki H, Honda M, Yazaki Y, Watanabe E, Luoma J, Yla-Herttuala S, Fraser I, Gordon S, Kodama T (1996) Involvement of specific macrophage-lineage cells surrounding arterioles in barrier and scavenger function in brain cortex. Proc Natl Acad Sci USA 93:3269-3274

Mato M, Sakamoto A, Ookawara S, Takeuchi K, Suzuki K (1998) Ultrastructural and immunohistochemical changes of fluorescent granular perithelial cells and the interaction of FGP cells to microglia after lipopolysaccharide administration. Anat Rec 251:330-338.

Matsumura K, Cao C, Ozaki M, Morii H, Nakadate K, Watanabe Y (1998) Brain endothelial cells express cyclooxygenase-2 during lipopolysaccharide-induced fever: light and electron microscopic immunocytochemical studies. J Neurosci 18:6279-6289.

McCarron RM (1992) IL-1-induced prostacyclin production by cerebral vascular endothelial cells inhibits myelin basic protein-specific lymphocyte proliferation. Cell Immunol 145:21-29.

Morimoto A, Murakami N, Nakamori T, Sakata Y, Watanabe T (1989) Possible involvement of prostaglandin $\mathrm{E}$ in development of ACTH response in rats induced by human recombinant interleukin-1. J Physiol (Lond) 411:245-256.

Polfliet MMJ, Goede PH, van Kesteren-Hendrikx EML, van Rooijen N, Dijkstra CD, van den Berg TK (2001a) A method for the selective depletion of perivascular and meningeal macrophages in the central nervous system. J Neuroimmunol 116:188-195.

Polfliet MMJ, Zwijnenburg PJG, van Furth AM, van der Poll T, Dopp EA, de Lavalette CR, van Kesteren-Hendrikx EML, van Rooijen N,
Dijkstra CD, van den Berg TK (2001b) Meningeal and perivascular macrophages of the central nervous system play a protective role during bacterial meningitis. J Immunol 167:4644-4650.

Polfliet MMJ, van de Veerdonk F, Dopp EA, van Kesteren-Hendrikx EML, van Rooijen N, Dijkstra CD, van den Berg TK (2002) The role of perivascular and meningeal macrophages in experimental allergic encephalomyelitis. J Neuroimmunol 122:1-8.

Priller J, Flugel A, Wehner T, Boentert M, Haas CA, Prinz M, Fernandez-Klett F, Prass K, Bechmann I, de Boer BA, Frotscher M, Kreutzberg GW, Persons DA, Dirnagl U (2001) Targeting genemodified hematopoeitic cells to the central nervous system: use of green fluorescent protein uncovers microglial engraftment. Nat Med 12:1356-1361.

Quan N, Whiteside M, Herkenham M (1998) Cyclooxygenase 2 mRNA expression in rat brain after peripheral injection of lipopolysaccharide. Brain Res 802:189-197.

Rivest S (1999) What is the cellular source of prostaglandins in the brain in response to inflammation? Facts and controversies. Mol Psychiatry 6:500-507.

Rivier C, Vale W, Brown M (1989) In the rat, interleukin-1 $\alpha$ and $-\beta$ stimulate adrenocorticotropin and catecholamine release. Endocrinology 125:3096-3102.

Sapolsky R, Rivier C, Yamamoto G, Plotsky P, Vale W (1987) Interleukin-1 stimulates the secretion of hypothalamic corticotropinreleasing factor. Science 238:522-524.

Sawchenko PE, Cunningham Jr ET, Mortrud MT, Pfeiffer SW, Gerfen CR (1990) Phaseolus vulgaris-leucoagglutinin (PHA-L) anterograde axonal transport technique. Methods Neurosci 3:247-260.

Scammell TE, Griffin JD, Elmquist JK, Saper CB (1998) Microinjection of a cyclooxygenase inhibitor into the anteroventral preoptic region attenuates LPS fever. Am J Physiol 274:R783-R789.

Schiltz J, Sawchenko P (2000) Differential recruitment of vascularassociated cell types to interleukin-1 versus endotoxin. Soc Neurosci Abstr 26:644.

Schindler R, Ghezzi P, Dinarello CA (1990) IL-1 induces IL-1. IV. IFN-gamma suppresses IL-1 but not lipopolysaccharide-induced transcription of IL-1. J Immunol 144:2216-2222.

Sehic E, Szekely M, Ungar AL, Oladehin A, Blatteis CM (1996) Hypothalamic prostaglandin E2 during lipopolysaccharide-induced fever in guinea pigs. Brain Res Bull 39:391-399.

Shu S, Ju G, Fan L (1988) The glucose oxidase-DAB-nickel method in peroxidase histochemistry of the nervous system. Neurosci Lett 85:169-171.

Simmons DM, Arriza JL, Swanson LW (1989) A complete protocol for in situ hybridization of messenger RNAs in brain and other tissues with radiolabeled single-stranded RNA probes. J Histotechnol 12:169-181.

Swanson LW, Kuypers HG (1980) The paraventricular nucleus of the hypothalamus: cytoarchitectonic subdivisions and organization of projections to the pituitary, dorsal vagal complex, and spinal cord as demonstrated by retrograde fluorescence double-labeling methods. J Comp Neurol 194:555-570.

van Dam A-M, Brouns M, Louisse S, Berkenbosch F (1992) Appearance of interleukin-1 in macrophages and in ramified microglia in the brain of endotoxin-treated rats: a pathway for the induction of non-specific symptoms of sickness? Brain Res 588:291-296.

van Dam A-M, de Vries HE, Kuiper J, Zijlstra FJ, de Boer AG, Tilders FJH, Berkenbosch F (1996) Interleukin-1 receptors on rat brain endothelial cells: a role in neuroimmune interaction? FASEB J 10:351-356.

Watanabe T, Morimoto A, Sakata Y, Murakami N (1990) ACTH response induced by interleukin- 1 is mediated by CRF secretion stimulated by hypothalamic PGE. Experientia 46:481-484.

Watkins LR, Maier SF, Goehler LE (1995) Cytokine-to brain communication: a review and analysis of alternative mechanisms. Life Sci 57:1011-1026.

Watts AG, Swanson LW (1989) The combination of in situ hybridization with immunohistochemistry and retrograde tract-tracing. In: Methods in neurosciences, Vol 1, Genetic probes (Conn PM, ed), pp 127-136. New York: Academic.

Zhang J, Rivest S (1999) Distribution, regulation and colocalization of the genes encoding the EP2 and EP4-PGE2 receptors in the rat brain and neuronal responses to systemic inflammation. Eur J Neurosci $11: 2651-2668$. 